\title{
Os Animais nas Cantigas de Santa Maria (II) The Animals in the Cantigas de Santa Maria (II)
}

\author{
Augusto de Carvalho MENDES \\ Universidade Federal de Minas Gerais \\ avgvstv@yahoo.com.br.
}

\begin{abstract}
Recibido: $05 / 01 / 2016$
\end{abstract}
Aceptado: 31/01/2016

Resumo: Nesse artigo foi analisada a representação dos animais nas Cantigas de Santa Maria, obra poética composta por Dom Afonso X, o Sábio. Para tanto, selecionamos todas as passagens das Cantigas de Santa Maria referentes aos animais e as comparamos com textos antigos e medievais, textos tanto da tradição simbólica quanto da científica, relativos a eles. Após um estudo sistemático, tanto dos textos quanto das ricas iluminuras que os acompanham, pudemos concluir que os animais são representados nas Cantigas de Santa Maria de um modo realista, em oposição ao modo simbólico, muito comum no período medieval. Tal característica observada na obra em questão é prenhe de conseqüências. Uma delas, que é abordada nesse artigo é que resultado desse estudo sistemático corrobora a tese de que as Cantigas de Santa Maria fazem parte da literatura gótica. Por fim, tentaremos articular a visão gótica do mundo com uma visão científica do mundo.

Palavras Chave: Cantigas de Santa Maria, animais, literatura gótica, visão científica do mundo.

\begin{abstract}
In this paper we analyzed the representation of animals in the Cantigas de Santa Maria, a poetry composed by the king Don Alfonso X the Wise. To do so, we selected all the passages of the Cantigas de Santa Maria concerning animals and compared with ancient and medieval texts relating to them. After a systematic study of both the texts and the rich illuminations that accompany them, we concluded that the animals are represented in the Cantigas de Santa Maria in a realistic way, opposed to symbolic way, very common in the medieval period. This characteristic observed in the work in question is full of consequences. One of them is that this systematic study corroborates the thesis that the Cantigas de Santa Maria are part of Gothic literature. Finally, we try to articulate the Gothic vision of the world with a scientific worldview.
\end{abstract}

Key Words: Cantigas de Santa Maria, animals, gothic literature, scientifc worldview.

Sumário: 4. Literatura Românica e Literatura Gótica. 4.1 O románico e seus fundamentos. 4.2 A literatura românica. 4.3. Símbolo e Alegoria. 5. O gótico e a ciência. 5.1. A ciencia biológica na Idade Média. 5.2. Cristianismo e ciência. 5.3. Arte gótica e a ordenação do mundo. 5.4. Linguagem e Pensamento. $5.5 \mathrm{O}$ realismo gótico e sua expressão da natureza. 6. Conclusão. Fontes e Bibliografía.

\section{Literatura Românica e Literatura Gótica}

$\mathrm{Na}$ secção anterior fizemos o inventário dos animais que aparecem nas Cantigas de Santa Maria. Escrevemos breves estudos sobre o significado atribuído a cada animal na cultura medieval e na obra poética de Dom Afonso X. Pudemos comparar os animais apresentados nas Cantigas com sua figuração em obras da Antigüidade e do período medieval e estudamos a função de alguns deles naquela sociedade. Apresentados os dados, vejamos qual é o seu significado. 
Vimos na primeira parte a forte simbolização que se fez dos animais na Idade Média, depois notamos como essa simbolização tem lugar marginal nas Cantigas de Santa Maria. A questão que se coloca é a seguinte: por qual motivo no os animais, na maioria das vezes, são retratados de forma natural, sem ganhar uma conotação simbólica no cancioneiro mariano de Dom Afonso X? Não temos uma resposta definitiva, mas iremos avançar algumas hipóteses.

Poderíamos levantar o que chamaremos de "hipótese ibérica": seria próprio da península ibérica uma visão mais realista do mundo, uma visão menos mítica e simbólica. Devemos considerar que aquela foi uma das regiões mais romanizadas da Europa na antiguidade: basta pensar nas Etimologias de Isidoro de Sevilha, composta com inúmeras citações de escritores romanos. Sabemos também que a mentalidade dos bárbaros germânicos não se espalhou de forma homogênea pela Europa medieval, sendo mais pronunciada no norte do continente. Conforme se vai descendo no mapa do velho mundo, constata-se menor presença do elemento germánico. ${ }^{1}$ A presença romana mais intensa na península ibérica poderia ser fonte de um maior racionalismo, menos propenso a aceitar o simbolismo do Fisiólogo.

Esse "racionalismo" ibérico poderia ser visto nas Cantigas de Santa Maria, por exemplo, quando se trata dos poderes taumatúrgicos atribuídos aos reis cristãos na cultura medieval. Na França e na Inglaterra a crença que os reis tinham poderes de cura era muito difundida, como demonstrou Marc Bloch. Contudo, como pudemos ver ao estudar a andorinha, nas Cantigas tal crença era claramente negada.

Outra hipótese que poderíamos levantar é a que chamaremos de "socialestilística": haveria um tratamento realista dos animais nas Cantigas de Santa Maria porque seu autor, Dom Afonso, não era um monge ou um religioso, mas um leigo, um rei, um homem que tinha contato com os animais reais nas atividades próprias de seu ofício: nas caçadas, nos banquetes e nas batalhas. Além disso, sua obra não é um Bestiário, mas uma coleção de poemas marianos.

Cremos que esses elementos são importantes, mas pensamos que não explicam cabalmente o realismo das Cantigas de Santa Maria. O fato de seu autor ser um poeta ibérico deve ter importância, mas não definitiva, já que na Península havia textos que tratavam os animais de forma simbólica e outros que usavam de interpretações simbólicas dos animais para construção da narrativa, como vimos no primeiro capítulo.

Que Dom Afonso X tenha contanto com os animais na qualidade de caçador ou comensal é certo, mas sua obra não é um tratado de caça seja de montaria, seja de alveitaria. As Cantigas de Santa Maria são uma obra religiosa e, portanto, é de se pensar que nelas veríamos a influência do pensamento religioso. Ora, o Fisiólogo e a maioria dos Bestiários são obras religiosas, além disso, é em escritos religiosos como os sermões que vemos muitos animais sendo usados como símbolos.

Considerando isso, vamos propomos outra explicação, a saber, os animais são figurados de modo naturalístico nas Cantigas de Santa Maria porque essa é uma obra de literatura gótica. $\mathrm{O}$ termo pode causar confusão já que é atribuído àquela

\footnotetext{
${ }^{1}$ Erich AUERBACH, Mimesis: a representação da realidade na literatura ocidental, São Paulo, Perspectiva, 2009, $15^{\text {a }}$ ed., p. 96.
} 
literatura nascida na Inglaterra do século XVIII, literatura de terror cheia de castelos e monstros. Não é disso que falamos.

Aqui nos filiamos à tese de Bernardo Monteiro de Castro, apresentada no livro As Cantigas de Santa Maria: um estilo gótico na lírica ibérica medieval, publicado em 2005 nos Estados Unidos da América e no ano posterior no Brasil, sua terra natal. Apesar de diversos pontos criticáveis, tal livro se constitui numa contribuição de grande importância para os estudos medievais por estender o estilo gótico ao campo da literatura. Tomando a obra do historiador da arte Michael Camille como ponto de partida, Bernardo Monteiro de Castro afirma que devemos caracterizar a arte gótica baseando-nos não tanto em aspectos estilísticos, mas no modo como esse estilo artístico representava certos temas de grande importância. Cinco são os temas escolhidos para caracterizar a literatura gótica, a saber: o espaço, o tempo, a natureza, Deus, o "si-mesmo". Algo bem diferente de arcobotantes, rosáceas, arcos ogivais e tantos outros elementos que normalmente são lembrados para caracterizar o gótico. Essa mudança de foco possibilita estudar o vasto corpus literário escrito na Idade Média com novos olhos e chegar a conclusões que dificilmente chegaríamos se focássemos somente nas métricas, narrativas e outros elementos analisados comumente pelos especialistas.

Nessa parte do artigo, não aprofundaremos todos os pontos considerados por Bernardo Monteiro de Castro, apenas tentaremos fundamentar um pouco mais sua hipótese com algumas investigações auxiliares deixadas de lado pelo autor.

Já que pretendemos apresentar algumas contribuições para o estudo da literatura gótica, uma pergunta necessária é a seguinte: ela existe? Isso é, podemos mesmo falar em literatura gótica? Antes de responder, façamos uma breve consideração. Muitos dos maiores estudiosos consideraram que uma das principais tarefas daquele que estuda as criações humanas é integrar os diversos movimentos espirituais e sociais de uma época num conjunto harmônico. É procurar a essência de uma série de ações e idéias aparentemente desconexas.

Arthur Oncky Lovejoy, o fundador do que se chama de History of Ideas no mundo anglo-saxão e inspirador de gerações de historiadores de língua inglesa, afirmava: "É nos ingredientes comuns lógicos ou pseudológicos ou afetivos por trás das dissimilaridades de superfície que o historiador de idéias individuais procurará penetrar" ". Por isso propunha ao historiador isolar uma "idéia-unidade" e procurá-la em todas as "regiões do mundo intelectual", ou seja, na "filosofia, ciência, literatura, arte, religião ou política" . Esse grande historiador entendia que a história das idéias deveria ser "uma tentativa de síntese histórica" no sentido de que estaria "especialmente interessada nos processos pelos quais a influência passa de um campo [do mundo intelectual] para o outro"4

Filiado a uma escola diferente, mas não menos erudito e influente, Erwin Panofsky, o grande historiador da arte, tinha como método tratar as obras pictóricas

\footnotetext{
${ }^{2}$ Arthur Oncky LOVEJOY, A Grande Cadeia do Ser: um estudo da história de uma ideia, São Paulo, Palíndromo, 2005, p.14.

3 Idem, p. 24.

${ }^{4}$ Ibidem, p.26.
} 
em consonância com as literárias, uma iluminando a outra. É claro que isso pressupõe certa relação entre um e outro tipo de arte. Aliás, é ele mesmo que lembra que por séculos os eruditos entenderam que há uma unidade nas diversas manifestações artísticas de cada época. ${ }^{5}$ Sobre essa unidade das artes comentava o filosofo espanhol Ortega y Gasset: "É, na verdade, surpreendente e misteriosa a compacta solidariedade consigo mesma que cada época histórica mantém em todas as suas manifestações. Uma inspiração idêntica, um mesmo estilo biológico pulsa nas artes mais diversas."

Ora, na apresentação da tese de Bernardo Monteiro de Castro, a professora Ângela Vaz Leão reafirma que segundo o autor o gótico não é só um estilo artístico, mas uma Weltanschauung. Não há como negar que ao procurar estender o conceito de gótico à literatura responde-se aos anseios, ainda sem resposta formal, de grandes eruditos do século passado.

Aliás, é importante notar que de forma tateante, não muito rigorosa, algo já foi dito sobre a literatura gótica. O já citado Erwin Panofsky tratou as obras arquitetônicas e pictóricas do gótico em conjunto com as literárias, revelando alguns traços comuns. A conciliação entre os desejos humanos e a caridade cristã, que teria se reforçado no século XIII, se encontraria na filosofia tomista, na arquitetura gótica e também em obras literárias como o Roman de la Rose, a Divina Comédia, nos escritos de Guido Guinicelli e outros seguidores do Dolce stil nuovo. ${ }^{8}$ Noutro livro, ele mostrará que os mesmos princípios de organização das catedrais se encontram em obras filosóficas e literárias. O grande historiador da literatura, Otto Maria Carpeaux, fala, en passant, do Parzival de Wolfram von Eschenbach como um obra cuja "idéia central é gótica"

Essas considerações parecem indicar, pelo menos inicialmente, a pertinência da abordagem de Castro. Mas, sendo ele, até onde sabemos, o primeira a tratar ex professo da literatura gótica, teria feito com o acerto? Uma inovação tão grande é bem possível de ser feita à custa do rigor. Como dissemos, a obra em questão poderia ser criticada de diversas formas, tanto por algumas argumentações pouco embasadas, quanto por algumas lacunas. Um dos pontos que acreditamos merecer um tratamento mais amplo é o da comparação histórica entre a literatura gótica e aquela que a precedeu. $\mathrm{O}$ autor dedica algumas páginas ao assunto ${ }^{10}$, mas o tema merece um aprofundamento.

\footnotetext{
${ }^{5}$ Erwin PANOFSKY, Significado nas artes visuais, São Paulo, Perspectiva, 1988, p.54.

${ }^{6}$ José ORTEGA Y GASSET, A Desumanização da Arte, São Paulo, Editora Cortez, 1991, p.20.

${ }^{7}$ Ângela Vaz LEÃO, Cantigas de Santa Maria de Afonso X, o Sábio: aspectos culturais e literários, Belo Horizonte, Veredas e Cenários, 2007, p.16

${ }^{8}$ Erwin PANOFSKY, Estudos de iconologia: temas humanisticos na arte do Renascimento, Lisboa, Estampa, 1986, p. 93.

${ }^{9}$ Otto Maria CARPEAUX, História da Literatura Ocidentel, Brasília, Edições do Senado Federal, 2008, v.1, p.220.

${ }^{10}$ Bernardo Monteiro de CASTRO, As Cantigas de Santa Maria: um estilo gótico na lírica ibérica medieval, Niterói, EDUFF, 2006, p.65-72.
} 
Nosso estudo busca, mesmo que muito parcialmente, apontar elementos que complementem a abordagem inicial do autor. Como pretendemos falar da literatura gótica, acreditamos que só será possível estabelecer suas especificidades em comparação com a arte gótica em geral e, é o que aqui faremos, com o estilo artístico anterior, o românico.

Sabemos que sempre é difícil determinar com precisão esses grandes períodos da história da arte. Onde acaba o românico e onde começa o gótico? Ou, para dar exemplos não medievais, quando se dá a passagem do maneirismo para o barroco, e do pré-romântico para o romântico? São questões complexas, mas acreditamos que Erwin Panofsky tem razão ao dizer que, mesmo sendo difícil precisar cronologicamente as mudanças de um estilo para o outro, é sempre possível distinguir a fisionomia de cada época artística. ${ }^{11}$ Como é sabido, o estilo românico precede o gótico. Começaremos nosso estudo tratando dele, tentando precisar suas características nas artes visuais. Feito isso, procuraremos ver se é possível falar da existência de uma "literatura românica" que antecederia a "literatura gótica".

\subsection{O românico e seus fundamentos}

Não há uma data precisa que possamos apontar como o início do românico. Aliás, a transição do pré-românico ao românico é algo difícil de definir. Aqui vale aquilo que citamos de Panofsky: é muito difícil determinar o início e o fim dessas grandes épocas artísticas, mas é possível reconhecê-las. Talvez, esse seja o motivo de certa divergência entre os historiadores sobre as datas. Segundo Raymond Oursel, o românico aparece no sul da França perto do ano de $950 .{ }^{12}$ Segundo Xavier Barral i Altet, o românico nasce propriamente no início do século XI, na região entre Toulouse e o norte da península Ibérica ${ }^{13}$.

Normalmente identifica-se o românico na arquitetura, na escultura e na pintura. É claro que cada uma dessas manifestações tem suas particularidades e que, dentro de cada uma delas, existe uma evolução que culminou na arte gótica e, além disso, uma grande variedade de expressão conforme os locais e as épocas. Não iremos considerar nem a história e nem as diversas particularidades das obras românicas, apenas tentaremos sintetizar algumas características da arte românica e ilustrar essa síntese com alguns poucos exemplos.

As igrejas românicas são mais amplas que as dos séculos anteriores devido ao aumento da população européia na época do seu surgimento, a qual, além das cerimônias litúrgicas, buscava nas igrejas as preciosas relíquias dos santos. Apesar de mais amplas, não podemos dizer que essas igrejas se tornam propriamente leves, as paredes continuam maciças, as pilastras grossas e os vidros escassos. A orientação das igrejas não era tão vertical como viria a ser no gótico, e não havia o efeito ascendente tão pronunciado que vemos nas igrejas desse último estilo. Isso se

${ }^{11}$ Erwin PANOFSKY, Renascimento e Renascimentos na Arte Ocidental, Lisboa, Presença, 1981, p.21

${ }^{12}$ Raymond OURSEL, Romanesque, Lausanne, Benedikt Taschen, 1967, p.128.

${ }^{13}$ Xavier BARRAL I ALTET, O mundo românico: cidades, catedrais e mosteiros, Köln, Taschen, 1999, p.46. 
dá por diversos motivos, um deles é que em alguns casos o escalonamento dos diversos níveis da igreja não é feito com elementos arquitetônicos verticais, como os arcos góticos, mas por divisões horizontais, feitas como que em camadas de pedra lisa. ${ }^{14}$

Outro fator que diminuía a sensação de amplitude da construção eram os tetos, muitas vezes retos ou com abóbadas arredondadas. $\mathrm{O}$ interior da igreja é, portanto, como que um paralelepípedo, sem algo que projete a visão de quem está nele para o alto. Mesmo nas basílicas, onde a nave central é mais alta que as laterais, a presença de grossas colunas e de paredes internas limita a sensação de ascensão. Algumas paredes chegavam a ter quase dois metros e meio de espessura, o que muitas vezes transmitia uma sensação de peso, de grande materialidade da construção.

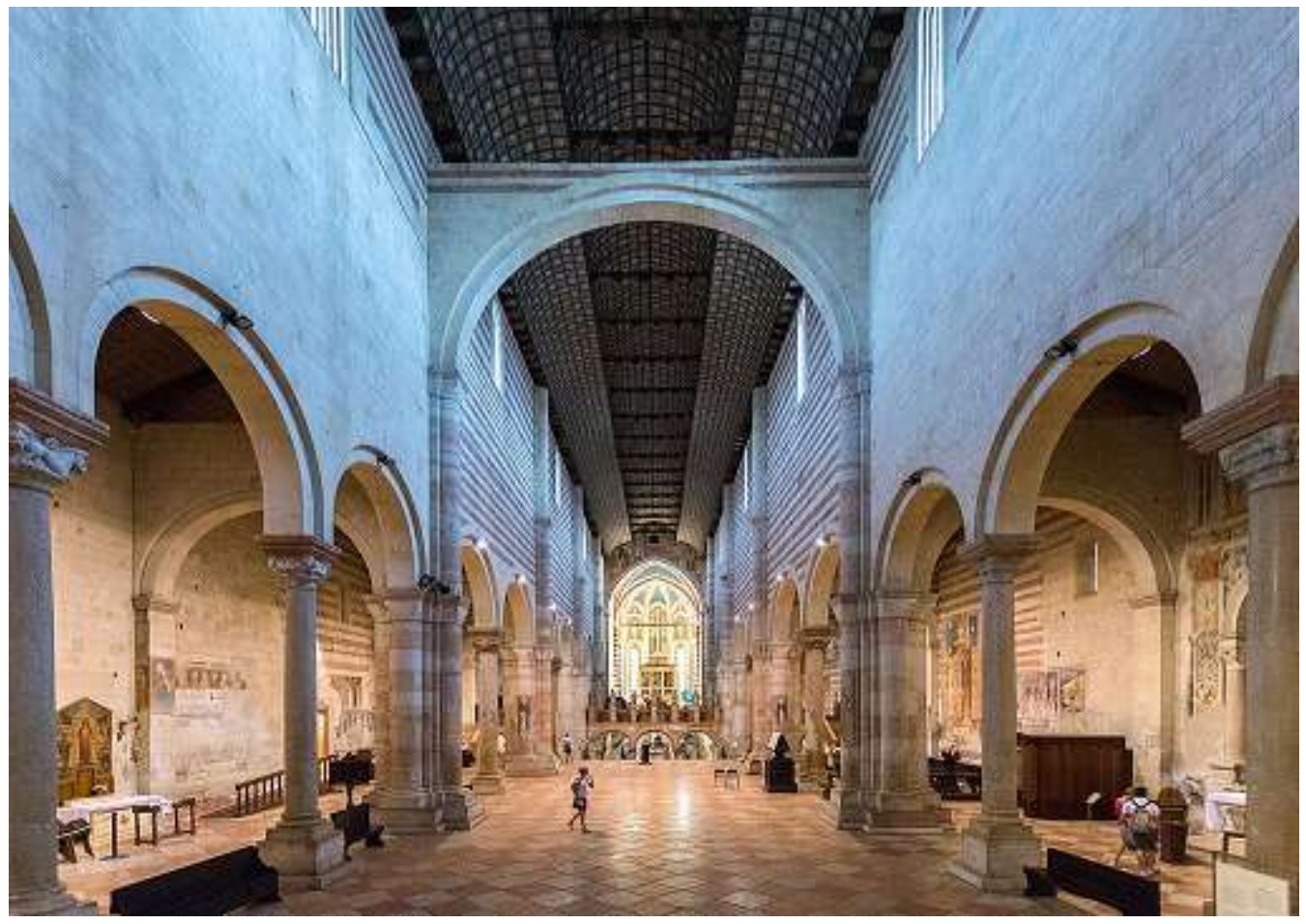

Fig.1 Nave da Basílica de São Zeno, século XI, Verona. Imagem tomada de Wikimedia Commons (Última consulta: 06/01/2016).

Consideremos alguns exemplos. A igreja da abadia beneditina de Maria Laach, construída na região alemã de Eifel, teria, segundo Ehrenfried Kluckert, a "essência da igreja românica perfeita". Quanto ao aspecto espacial do interior da igreja, poderíamos dizer, seguindo sua análise, que a abóbada da igreja "produz um efeito de esmagamento" e "ressalta o aspecto grave e compacto do espaço"15. Esse espaço grave, fechado e esmagador, pode ser encontrado em outras igrejas românicas, especialmente as mais antigas, mas também em algumas mais modernas. Da catedral de Braunschweig, por exemplo, o mesmo estudioso afirma o seguinte:

${ }^{14}$ Alick MCLEAN, A Arquitetura românica na Itália. In: TOMAN, Rolf (org.), O Românico: Arquitectura, Escultura, Pintura, Madrid, Könemann Verlagsgesellschaft, 2000, p.102.

${ }^{15}$ Ehrenfried KLUCKERT, Arquitectura da construção sacra românica. In: Rolf TOMAN (org.), O Românico: Arquitectura, Escultura, Pintura. Madrid, Könemann Verlagsgesellschaft, 2000, p.58 
A catedral de Braunschweig foi reconstruída entre 1173 e 1195; a basílica cruciforme foi concebida para receber uma abóbada contínua, e na sua nave central observa-se uma alternância de suportes simples; os suportes intermédios não são colunas pequenas, mas sim pilares frágeis que dão a idéia de restos de paredes. O clerestório mal iluminado e a abóbada combinam-se-lhes, formando um corpo pesado, quase cavernoso. ${ }^{16}$

Lembremos que se trata de uma catedral, uma igreja normalmente maior que as demais. Evidente que existem exemplares de igrejas românicas amplas, que transmitem maior sensação de leveza, especialmente na Inglaterra, mas nada que se compare ao que se verá no gótico. A iluminação natural das igrejas românicas era inferior a das igrejas góticas porque suas janelas eram menores, algumas não passando de frestas, como as da igreja de São Zeno (fig.1). Apesar disso, havia forte preocupação, pelo menos em igrejas maiores, com uma iluminação interna, feita com velas e tochas.

Poderíamos pensar num paralelo entre essa concepção interior de luminosidade de uma igreja e a teologia da época. A teologia medieval anterior à escolástica consiste, basicamente, em comentários e explicações da Sagrada Escritura. É uma teologia fechada na Revelação, no sentido que encontra todos seus elementos, todo ou quase todo o seu saber, naquilo que foi consignado na Bíblia. Os saberes filosóficos não tinham um papel tão importante na Teologia como teriam na escolástica. Assim, tanto a igreja românica quanto a teologia pré-escolástica se fecham ao mundo profano e buscam quase toda sua luz no sagrado. A catedral gótica e a escolástica farão de modo diverso: procurarão usar da luz do mundo natural para deixar as realidades divinas mais claras e inteligíveis para os homens. Uma igreja românica, vista do exterior, por vezes transmite a sensação de ser uma fortaleza contra o mundo exterior. ${ }^{17}$

$\mathrm{Na}$ verdade, ela era construída para ser uma representação na terra da Jerusalém Celeste, a cidade que abrigará os eleitos no céu. A concepção que se tinha dessa cidade celeste descrita no Apocalipse era fortemente marcada pela interpretação dada por Santo Agostinho. ${ }^{18}$ Santo Agostinho concebeu dois agentes históricos, duas cidades, aquela dos homens que se colocam orgulhosamente acima de Deus e aquela dos que amam a Deus mais que a si mesmos. Evidente que a Jerusalém Celeste era a pátria derradeira desses últimos. Vemos, portanto, que a igreja românica se constrói em oposição ao mundo terreno. Talvez por isso ela abrigue mais elementos míticos e imaginários do que realistas e cotidianos. Voltaremos a esse ponto em breve.

\footnotetext{
${ }^{16}$ Idem, p.67.

${ }^{17}$ Bruno KLEIN, A arquitectura românica em Espanha e Portugal, In: Rolf TOMAN (org.), O Românico: Arquitectura, Escultura, Pintura. Madrid, Könemann, 2000, p.198

${ }^{18}$ Ehrenfried KLUCKERT, A pintura românica, In: Rolf TOMAN (org.), O Românico: Arquitectura, Escultura, Pintura. Madrid, Könemann, 2000, p.434.
} 
Retornando à questão da iluminação, talvez seja essa firme separação entre um espaço sacro e um espaço profano que explique o intenso uso de iluminação artificial no interior da igreja a despeito da iluminação natural que viria do seu exterior. Não só iluminação, mas uma forte presença de elementos decorativos no seu interior contrastando com um exterior relativamente pouco ornamentado. Cluny, a grande igreja românica, é paradigmática quando se trata de riqueza decorativa:

\begin{abstract}
A decoração deve ter sido esplendorosa. À excepção dos belos capitéis, os quais prendiam a vista desde qualquer lugar da sala, bandas ornamentais esculpidas emolduravam todos os arcos, janelas e cornijas. Os pilares eram canelados. A isto acrescentavam-se aros coloridos à volta de todos os elementos arquitetônicos, pinturas, tapetes, enormes rosáceas que espalhavam uma luz mística, figuras de santos, incenso, paramentos bordados a ouro, alfaias litúrgicas de ouro e prata, adornadas com pedras preciosas e, acima de tudo, os cânticos, que, de algum modo já no tempo de Cluny II, mas de forma definitiva apenas a partir de Cluny III, se haviam tornado o elemento essencial da liturgia ${ }^{19}$.
\end{abstract}

Nessas igrejas encontramos esculturas e pinturas como decoração. A escultura românica é fortemente ligada à arquitetura. Ao contrário da escultura clássica e da gótica, a escultura românica, na quase totalidade das vezes, não é uma escultura de plástica livre, ou seja, não é completamente esculpida. A escultura românica não é propriamente um objeto tridimensional, é mais como um relevo, mais ou menos ligada à parede. ${ }^{20}$

Erwin Panofsky demonstrou que a escultura antiga, especialmente a grega clássica, tinha o seu centro em si mesma, o que a destacava da construção arquitetônica. A mobilidade da escultura grega clássica se originava do seu interior, como num ser vivo, e assim se contrapunha, imaginariamente, é claro, aos objetos inanimados, como os templos. ${ }^{21}$ Os escultores românicos, mesmo quando se baseavam nos antigos, não desenvolveram esse tipo de escultura porque, como dissemos, esculpiam relevos e não esculturas. E esculpiam assim porque concebiam a escultura como intrinsecamente ligada à arquitetura.

É como se cada ser individual não tivesse existência se não estivesse num conjunto mais amplo. Sua individualidade não existia, pois estava absorvida no conjunto da obra. Não seria muito diferente de certas correntes filosóficas muito em voga até o século XII. A primeira delas, já defendida por Platão, Porfírio e Boécio, afirmava que a realidade fundamental dos seres se encontra propriamente não neles,

\footnotetext{
${ }^{19}$ Bernhad e Ulrike LAULE, A arquitetura românica em França, In: Rolf TOMAN (org.), $O$ Românico: Arquitectura, Escultura, Pintura, Madrid: Könemann, 2000, p.130.

${ }^{20}$ Uwe GEESE, A escultura románica, In: Rolf TOMAN (org.), O Românico: Arquitectura, Escultura, Pintura, Madrid, Könemann, 2000, p.256.

${ }^{21}$ Erwin PANOFSKY, Renascimento e Renascimentos na Arte Ocidental, Lisboa, Presença, 1981, p.93.
} 
mas nos seus modelos supra-sensíveis. ${ }^{22}$ A outra opinião, consideravelmente difundida entre os teólogos medievais, era de que em cada ser individual existia toda a espécie, sendo as diferenças individuais apenas acidentais. Sócrates não é propriamente um indivíduo, mas apenas uma manifestação da humanidade com algumas características individuais menos importantes. ${ }^{23}$ Todos os homens seriam como as pontas emersas de uma enorme ilha: vistas de cima, cada uma dessas pontas pareceriam pequenas ilhas individuais, mas vistas de baixo, observadas mais profundamente, se revelariam apenas pedaços de uma grande ilha. Na teologia, tal visão foi abandonada no final do século XI. Alguns anos depois a Europa viria o gótico nascer.

Voltando à questão da representação artística, é só com o gótico que ela irá mudar, pois a escultura passa a ser concebida com um centro em si mesma, passa a ser como que um indivíduo no cosmos da arquitetura. Em outras palavras, como Erwin Panofsky bem demonstrou, a escultura medieval foi deixando de ser um mero relevo e, já no gótico, ganhou autonomia da construção, passando a ter seu movimento originado em si mesma. ${ }^{24}$ Outras considerações devem ser colocadas a respeito da forma das esculturas românicas:

No que respeita à forma e ao conteúdo, a escultura românica é hierática, pois apresenta formas acentuadamente solenes, estáticas e muitas vezes rígidas, inspiradas em tradições religiosas. Assim sendo, as pregas no vestuário e a postura, bem como a representação das mãos e dos pés ou de rostos obtêm caráter representativo, o que empresta à obra românica marcas reconhecíveis a nível internacional. ${ }^{25}$

O exemplo mais identificável dessa escultura hierática são as diversas representações da Virgem Maria com o Menino Jesus. Apresentam poucos traços de afetividade, não se movem, não interagem. Além disso, não há grande diferenciação de idade e sexos, ambos parecem adultos e algo masculinizados. A mesma especialista acredita que, na escultura românica, muito do que é representado, inclusive os animais, o é por seu valor simbólico:

Para além destas [das formas], a arte do românico contém inúmeros símbolos que por vezes já não são compreensíveis aos olhos de hoje. Entre eles encontram-se não só as representações animais, muito

\footnotetext{
${ }^{22}$ Josep-Ignasi SARANYANA, A Filosofia Medieval: das origens Patrísticas à Escolástica Barroca, São Paulo, Instituto Brasileiro de Filosofia e Ciência "Raimundo Lúlio" (Ramon Llull), 2006, p.176-177.

${ }^{23}$ Idem, p.178-180

${ }^{24}$ Erwin PANOFSKY, Renascimento e Renascimentos na Arte Ocidental, Lisboa, Presença, 1981, p.93-95.

${ }^{25}$ Uwe GEESE, A escultura románica, In: Rolf TOMAN (org.), O Românico: Arquitectura, Escultura, Pintura, Madrid, Könemann, 2000, p.256.
} 
difundidas, ou os seres híbridos do bestiário da época, mas também os significados simbólicos de alguns algarismos ou pedras preciosas. ${ }^{26}$

Segundo a autora, o conteúdo da arte românica é muitas vezes de caráter simbólico, não podendo ser apreendido imediatamente. Uwe Geese cita os animais como exemplo, afirmando que eles são representados não por suas qualidades naturais, mas por simbolizarem outras realidades, como nos bestiários. Vemos, portanto, que tanto a forma quanto o conteúdo da escultura românica concorrem para representar o mundo de uma forma simbólica e pouco natural. O mesmo poderíamos encontrar na pintura, seja mural, seja de livros, da arte românica. E como era representada a natureza nesse período? Deixemos São Bernardo de Clavaral contar:

No claustro, debaixo dos olhos dos irmãos, que ali se dedicam às leituras sagradas, que fazem esses monstros ridículos, essa maravilhosa deformada beleza, ou esse bela deformidade? Que proveito existe nesses imundos macacos, nesses leões ferozes, nesses absurdos centauros, nesses tigres listrados, nesses cavaleiros que pelejam, nesses caçadores que sopram suas trompas? Vêem-se aí muitos corpos com uma só cabeça, ou muitas cabeças num só corpo. Ora é um animal quadrúpede com cauda de serpente; ora um peixe com cabeça de quadrúpede. Aqui é a parte dianteira de um cavalo que arrasta atrás de si a parte traseira de uma cabra; acolá um animal cornudo que tem o traseiro de um cavalo. Em suma, descobre-se uma tão rica e interessante variedade de formas, onde quer que apareçam, que somos mais tentados a ler no mármore do que em nossos livros, e a passar o dia inteiro contemplando tais coisas, em vez de meditar na lei de Deus. Pelo amor de Deus, se os homens não se envergonham dessas frivolidades, que, pelo menos, evitem tão grandes despesas! $!^{27}$

Segundo esse grande asceta, havia até um excesso nas representações da natureza. Mas, retomemos a pergunta do santo monge; para que representavam os seres da natureza? Podemos pensar em três motivos básicos. O primeiro seria a vontade de decorar o ambiente. Esse motivo é óbvio, pois uma das funções da arte é justamente a decorativa. Seria o caso do mosteiro visitado por São Bernardo. Vejamos que ele mesmo parece não ver nenhuma utilidade, a não ser decorativa, naquelas esculturas. Mas, porque animais e monstros como decoração? Pelo tipo de composição, podemos pensar que se trata de um gosto muito antigo, bárbaro, que se apresenta ainda no românico. ${ }^{28}$ Os animais esculpidos seriam os descendentes dos

\footnotetext{
${ }^{26}$ Idem, p256-257.

${ }^{27}$ Apud Armindo TREVISAN, O Rosto de Cristo: a formação do imaginário e da arte cristã, Porto Alegre, AGE Editora, 2002, p.99.
}

${ }^{28}$ Alick MCLEAN, A Arquitetura românica na Itália In: Rolf TOMAN (org.), O Românico: Arquitectura, Escultura, Pintura, Madrid, Könemann, 2000, p.84. 
monstros das lendas germânicas, seriam um resquício de uma visão algo mítica da natureza e do homem. Nessa visão, pelo menos na sua configuração primitiva, os homens não se diferenciariam tanto dos outros seres vivos, veriam-se como que ligados a eles por nexos mágicos. Daí colocá-los em suas casas e seus templos.

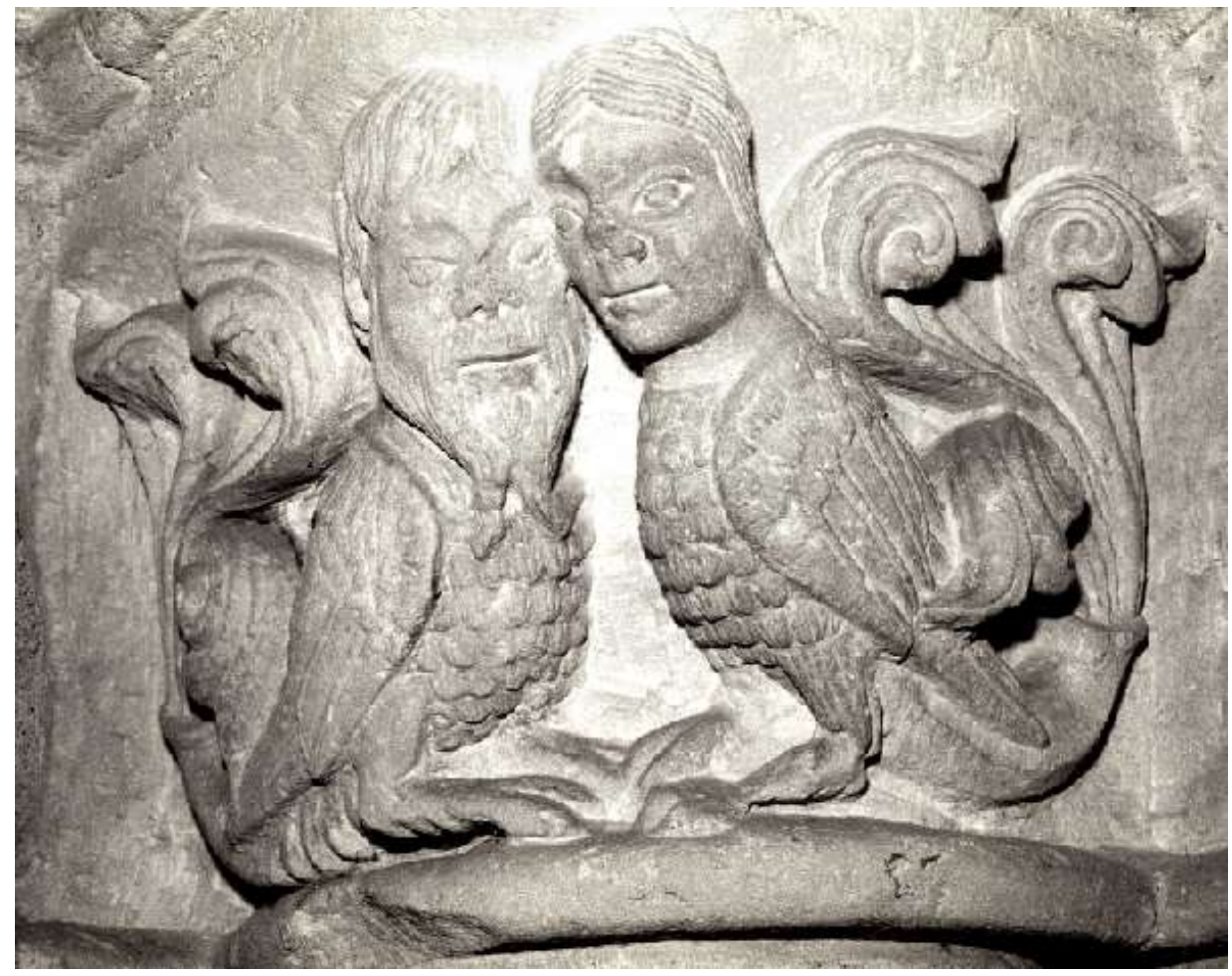

Fig.2 Animais fantásticos, capitel. Igreja de Saint Ours, século XII, Loches. Imagem tomada de http://peregrinations.kenyon.edu/vol2-1/loches1/loches1.html (Última consulta: 06/01/2016).

Outro grande motivo para a representação dos animais na arte românica seria o de divulgar ensinamentos religiosos e morais. Vejamos, por exemplo, a seguinte opinião do monge Hugo de Folieto:

Clamor anseris urbem Romam ab impetu hostium seruauit immunem; clamor discreti fratris, ne turbetur a peruersis, custodit uitam communem. Forsitan Diuina Prouidentia naturas uolucrum nobis non proponeret, nisi eas in aliquo nobis forte prodesse uellet. ${ }^{29}$

Não se pode dizer que isso é o pensamento de um obscuro monge. Como demonstrou Rémi Brague, muitos foram os filósofos, antigos e medievais, gregos, latinos, árabes e judeus, que consideraram o estudo do mundo natural completamente carente de importância. O reputado historiador muçulmano

\footnotetext{
${ }^{29}$ O grasnar do ganso preservou a cidade de Roma do assalto inimigo; o clamor do Irmão prudente protege a vida da comunidade, para não ser perturbada pelos perversos. Talvez a Divina Providência não nos pusesse diante dos olhos a natureza das aves, se não quisesse que elas nos fossem úteis nalguma coisa. (Hugo de FOLIETO, Livro das Aves, Lisboa, Edições Colibri, 1999, p.145)
} 
medieval, Ibn Khaldun, é mais contundente que nosso monge: "Os problemas de física [da natureza] não têm importância para nós nem do ponto de vista de nossa religião, nem do de nossa subsistência. Devemos, portanto, nos desviar deles." ${ }^{" 30}$

Também são conhecidas as duras condenações emitidas por al-Ghazali contra os filósofos gregos e suas doutrinas que não harmonizavam com a crença islâmica, bem como contra o estudo da matemática. ${ }^{31}$ Entre os gregos, Epicuro defendia posição semelhante, e, na Europa medieval, Hugo de Folieto não estava só.

Essa concepção da natureza exposta por Hugo de Folieto é a que se mostra em milhares de esculturas e pinturas românicas. E é essa mentalidade que preside toda a tradição do Fisiólogo e de muitos bestiários, como vimos anteriormente. Podemos, portanto, dizer que os animais são representados de modo duplamente arealista ou a-natural. Isso porque eles são representados devido ao seu caráter simbólico ou mítico, que é algo que não está inscrito nas suas naturezas. Além disso, e dependente desse último ponto, muitas vezes o animal é representado de forma que quase não se relaciona com a sua realidade natural: o animal é figurado de forma muito abstrata, quase não sendo possível identificá-lo.

Ao observarmos ilustrações de bestiários românicos, muitas vezes só conseguimos identificar o animal pela inscrição ou legenda que a imagem recebe. A ilustração do crocodilo que apresentamos na primeira parte desse artigo nada revela de um crocodilo real. Observando-a, nunca poderíamos identificar nela um réptil com escamas e cauda. Muitas outras ilustrações românicas nos dão a mesma impressão, no Bestiário de Oxford, cujas iluminuras foram reproduzidas no livro de Ignácio Malaxecheverría, vemos leões que mais se parecem com panteras, tigres sem listras e aves com cores totalmente irreais, como uma águia vermelha ou uma perdiz com listras verdes, vermelhas, brancas e pretas. ${ }^{32}$

Não se trata de falta de habilidade dos artistas, mas simplesmente de pouco interesse em representar o animal real. A razão disso é óbvia: se o animal vale por aquilo que ele simboliza e não por aquilo que ele é, pouco importa sua forma corporal, o que conta mesmo é seu valor moral. Os macacos, por exemplo, eram representados sem cauda por uma questão de simbolismo. ${ }^{33}$

Não faltam estudiosos da arte românica que afirmem que representar a natureza com fidelidade não era uma das preocupações dos artistas. ${ }^{34} \mathrm{E}$ nesse ponto ela difere muito claramente da arte gótica. A arte gótica é visivelmente mais realista. Um exemplo disso é a facilidade de reconhecer os animais das iluminuras das

30 Apud Rémi BRAGUE, Mediante a Idade Média: filosofias medievais na cristandade, no judaísmo e no islã São Paulo, Loyola, 2010, p. 109.

${ }^{31}$ Edward GRANT, Os Fundamentos da Ciência Moderna da Idade Média, Porto, Porto Editora, 2002, p.209-211.

32 Ignácio MALAXECHEVERRÍA, Bestiário Medieval, Madrid, Ediciones Siruela, 1993, p. 261-276.

${ }^{33}$ Janetta Rebold BENTON, Bestiaire Medieval: les animaux dans l'art du Moyen Age, Paris, Editions Abbeville, 1992, p.86-87.

${ }^{34}$ Raymond OURSEL, Romanesque, Lausanne, Benedikt Taschen, 1967, p.181. 
Cantigas de Santa Maria. Esse aspecto realista da arte gótica é reconhecido por uma série de autores; citemos apenas um, Marcel Aubert, que se expressa com clareza:

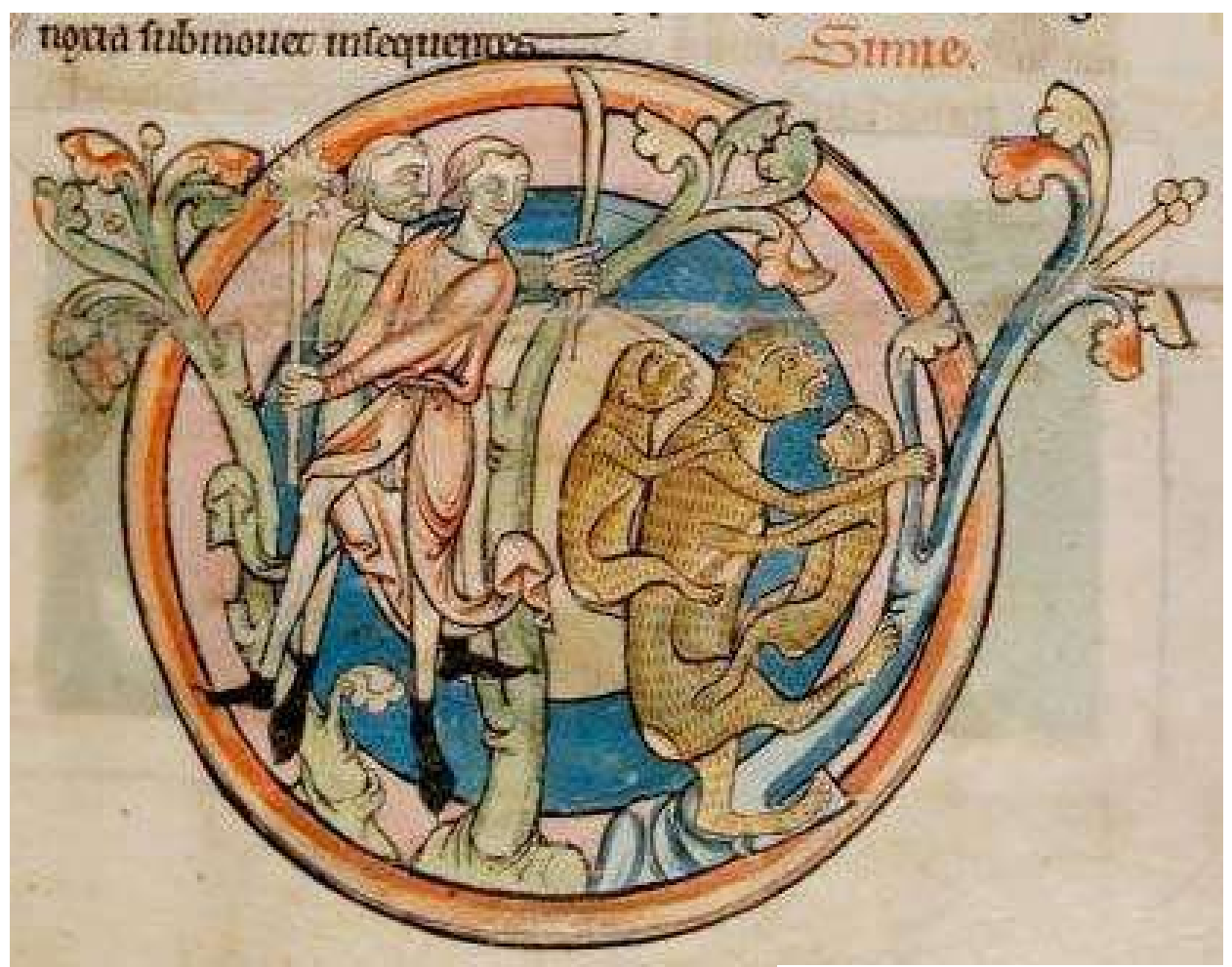

Fig.3. Macacos sem as caudas, c.1230-1240, Inglaterra'British Library, Harley MS 4751, f. 11 r. Imagem tomada de http://bestiary.ca (última consulta 06/01/2016)

Os artistas já não se contentam em repetir fórmulas de oficina: aprenderam a amar a Natureza, as flores do campo e as folhas dos bosques. Era possível reconhecer, no começo do século XIII, na fachada de Notre-Dame de Paris, os novos motivos inspirados na roseira brava, no morangueiro, na vinha, no agrião, no feto, no carvalho, no ácer, nas espécies mais simples da Natureza, que desabrochavam na Primavera. ${ }^{35}$

Com isso concluímos nossa breve exposição sobre a arte românica. Fizemos também algumas comparações com a arte gótica, marcando mais a diferença entre os dois estilos. Estudemos agora a literatura românica.

\subsection{A literatura românica}

Pelo que vimos até agora seria possível falar de uma literatura românica? Acreditamos que sim, mas devemos nos conformar com um resultado precário e muitíssimo parcial. Não estamos em condição de definir com segurança o que seria essa literatura românica, só buscaremos uma abordagem inicial do tema, esperando pesquisas posteriores que a completem. Procuremos algumas das características que

\footnotetext{
${ }^{35}$ Apud Armindo TREVISAN, O Rosto de Cristo: a formação do imaginário e da arte cristã, Porto Alegre, AGE Editora, 2002, p.149.
} 
vimos nas artes visuais e vejamos se elas podem ser encontradas na literatura medieval.

Não podemos considerar os primeiros escritos da Idade Média como representantes dessa literatura românica, seus autores estão ainda bastante vinculados às letras clássicas, a autoria é marcadamente individual, os temas são tratados de modo muito particularizado e pessoal. Santo Agostinho é singular, seu estilo elaborado não se afasta tanto do ideal antigo, e é diretamente em fontes romanas que o vemos beber. Sua presença como autor é muito palpável, basta lembrar que foi ele o inventor da autobiografia! Devemos avançar mais para encontrarmos uma literatura que tenha características semelhantes às da arte românica. A literatura medieval germânica é ainda muito pouco cristã e de temas muito ligados à vida daqueles povos, pouco lembrando os temas da arte românica.

É de crer que, se estamos falando de visões de mundo, a visão de mundo românica apareça mais ou menos na mesma época, tanto na literatura quanto nas artes visuais. Vamos, portanto, analisar a literatura do período em que se encontra o românico nas artes visuais, ou seja, a literatura do século XI e XII. Procuremos, pois, algumas das características estudadas acima, em obras desse período.

Vimos que as igrejas românicas muitas vezes transmitem uma sensação de estreiteza, de fixidez, de algo que esmaga o homem. Estudando a Chanson de Roland, Erich Auerbach sintetiza o modo do poema representar o mundo da seguinte forma:

O poeta nada explica; e, contudo, o que realmente acontece é pronunciado com um rigor paratático que exprime que tudo devia acontecer como acontece, nem poderia ser de outro modo, e não precisa de membros de ligação com fins explicativos. Isto refere-se, como é sabido, não somente aos acontecimentos, mas também às opiniões e princípios, sobre os quais repousa a ação das personagens. $\mathrm{O}$ cavalheiresco desejo de lutar, o conceito de honra, a mútua fidelidade entre companheiros de armas, a comunidade de castas, o dogma cristão, a divisão do justo e do injusto entre fiéis e infiéis, constituem, certamente, os princípios mais importantes. São poucos. Apresentam um quadro estreito, no qual aparece somente uma camada social, e mesmo esta, de maneira muito simplificada. Tais princípios são colocados sem motivação, como pura tese: assim é. ${ }^{36}$

Esse é um mundo dado. Esse tipo de mundo não é propriamente o mundo humano com suas infindas variações e contradições. É um mundo estreito, e seus personagens não são tão autores de suas vidas, estão como que fundidos nos curso dos acontecimentos. São como as esculturas românicas que estudamos pouco antes. Outro exemplo que poderíamos dar desse estreitamento do mundo, colhido numa obra de um gênero diverso da Chanson de Roland, é o da Chanson de Saint Aleixis, uma hagiografia do século XI. Conta a história de Aleixo, filho único e temporão de

${ }^{36}$ Erich AUERBACH, Mimesis: a representação da realidade na literatura ocidental, São Paulo, Perspectiva, 2009, $15^{\text {a }}$ ed., p. 87. 
uma nobre família romana que acaba casando para fazer a vontade de seu pai, mas abandona a mulher sem tocá-la e vai viver entre mendigos na Síria para servir a Deus. Lá passa a ser considerado um homem santo e volta para Roma fugindo de qualquer homenagem. Já na Cidade Eterna, vive debaixo das escadas da casa de seu pai como mendigo, não reconhecido, por dezessete anos, "sem se comover com a dor dos pais e da noiva, cujas queixas ouve amiúde, sem dar-se a conhecer. Só após sua morte é reconhecido de forma miraculosa e honrado como santo.",37

Uma história como essa poderia ser contada de modo muito dramático, agitado, cheio de reveses e surpresas emocionantes. Poderia ser narrada de modo tenso e envolvente, pois se trata de uma história, pelo menos no conteúdo, cheia de dificuldades, de problemas humanos árduos: a obediência, a separação dos amantes, o sacrifício das riquezas por uma causa maior... Mas não é nada disso que vemos na narrativa:

Tudo está fixo, o branco e o preto, o bem e o mal, e não precisa de mais pesquisa nem de justificação alguma; certamente existe tentação, mas não existe problemática. De um lado está o serviço de Deus, que leva para longe do mundo e para a salvação eterna - do outro, a vida natural no mundo, que leva a "grande tristeza". A consciência não conhece outras situações, e a realidade exterior - tudo o mais que o mundo ainda oferece e dentro do qual os acontecimentos narrados precisam ser encaixados de alguma maneira - é de tal forma reduzida que nada resta além de um pano de fundo inessencial para a vida do santo. Ao seu redor, acompanhando-lhe os atos com gestos apropriados, o pai, a mãe, e a noiva; de maneira ainda mais vaga e indistinta delineiam-se algumas outras personagens necessárias para a narração; o resto é inteiramente esquemático, tanto do ponto de vista sociológico, quanto geográfico. Isto é tanto mais surpreendente, quanto a cena parece abranger toda a ampla variedade do Império Romano; de Oriente e de Ocidente nada sobrou além de igrejas, vozes do céu, povo rezando - nada além do ambiente sempre igual de uma vida de santo. [...] O mundo tornou-se muito pequeno e estreito e nele se trata, rígida e inamovivelmente, de uma única pergunta, já respondida de antemão, à qual o homem só deve dar a resposta adequada. ${ }^{38}$

Acreditamos que essa longa citação poderia ser condensada da seguinte maneira: a Chanson de Saint Aleixis apresenta um mundo fechado no qual só existem dois caminhos para o homem seguir, os dois caminhos são claramente conhecidos e o caminho correto é conhecido de antemão. Não há a ambigüidade própria da vida humana, o conflito entre a vontade e o dever, entre a norma geral e sua aplicação concreta. Esse mundo estreito nos lembra a igreja românica, como a caracterizamos acima, fechada para o século.

\footnotetext{
${ }^{37}$ Idem, p. 98 .

${ }^{38}$ Ibidem, p.96-97.
} 
A claridade dos eventos, o bem se apresentando como bem e o mal como mal nos lembra, mais uma vez, a igreja românica que se fecha para a variedade do mundo, mas se ilumina por dentro. Aleixo, abandonando o mundo, sendo um homem religioso, vê as coisas claramente, o bem como o bem e o mal com o mal. Seu mundo é estreito, mas é transparente. Não têm as confusões próprias da realidade humana. $\mathrm{O}$ mesmo parece ocorrer nas artes plásticas na época românica. $\mathrm{Na}$ escultura românica não conhecemos algo equivalente ao "príncipe do mundo" esculpido na fachada ocidental de catedral de Estrasburgo entre 1280 e 1290. Tratase de um

diabólico mas belo e jovem príncipe que, com um sorriso sedutor, oferece uma maçã a uma das Virgens Loucas numa óbvia referência à Tentação de Eva. O que ela não pode ver, mas é claramente visível ao espectador, são as repugnantes costas putrefatas do príncipe, infestadas de serpentes, sapos e largatos, a anteciparem o cruel tratamento dos corpos mortos nas tumbas transi do fim do século XIV e também mais tarde. $^{39}$

E nas Cantigas de Santa Maria, obra da literatura gótica, quantas situações complicadas nós podemos ver! A confusão da realidade está lá: há o cristão que é ladrão, há o meirinho que rouba e engana a pobre vendedora, há o ovelheiro que também faz isso e culpa o lobo, há até mesmo o filho do diabo, Merlin, rezando e pedindo a Deus um milagre que mostre a um judeu que Ele realmente Se encarnou!

Acreditamos ter encontrado uma diferença marcante entre a concepção românica e a gótica da vida humana. Vemos na primeira uma vida moral simples e esquemática, o que não se apresenta na segunda. Não que a visão gótica coloque dúvidas sobre o que é o bem e o que é o mal, ou que eles existam objetivamente. A diferença é que na visão gótica temos uma visão mais realista das coisas, onde o bem e o mal aparecem mais mesclados, com maiores nuances. Não deixa, de modo algum, de ser uma visão objetiva e religiosa das realidades morais, mas já encarna aquela verdade, expressa de forma lapidar alguns séculos mais tarde por um conhecido religioso brasileiro: "nenhuma vida é um axioma".

Essa visão "românica" da moral parece implicar um cristianismo ainda pouco entranhado na população em geral. Evidente que havia muitos homens realmente religiosos, mas eles eram monges e, portanto, de um estrato bastante determinado da sociedade medieval. Erich Auerbach é da opinião de que a literatura dessa época apresenta essa característica simplista não por ser cristã, mas por outros fatores sociais. Otto Maria Carpeaux entende que as principais epopéias do século XII têm esse mesmo tom:

Os costumes que a epopéia apresenta são um grande anacronismo; os guerreiros do século VIII aparecem como cavaleiros feudais; está em contradição com isso o exagero, evidentemente primitivo, das forças

\footnotetext{
${ }^{39}$ Paul WILLIAMSON, Escultura Gótica 1140-1300, São Paulo, Cosac \& Naify Edições, 1998, p.193.
} 
físicas e das façanhas corporais. Sentimentos mais delicados não existem - além do forte sentimento de honra - e não há nenhum vestígio de psicologia. Mas, com isso, o poema está perfeitamente caracterizado. Os costumes feudais e as expressões religiosas não passam de um verniz. A Chanson de Roland representa a época em que os franceses estavam mal cristianizados, e, por assim dizer, ainda não eram franceses. Eram francos. Assim como no Poema de mio Cid castelhano subsiste o espírito visigótico, e assim como no Nibelungenlied alemão subsiste o espírito escandinavo, assim também a Chanson de Roland pertence à época da transição entre a barbaria germânica e a civilização francesa. ${ }^{40}$

Acreditamos que é possível entender essas obras como integrantes do que estamos chamando de literatura românica. Como a Chanson de Roland, também o Cid e o Nibelungenlied apresentam esse mundo moral restrito. Carpeaux dirá, por exemplo, que a história do Cid é "dura e sólida como os muros românicos de Ávila". 41

Em outros gêneros literários do século XII, e mesmo do século XIII, podemos encontrar elementos semelhantes. $\mathrm{O}$ mundo psicológico e moral fechado e esquemático e uma natureza mítica ou simbólica. O leitor de Chrétien de Troyes, grande romancista francês do século XII, verá certa diferença entre suas obras e as epopéias, o mundo parece mais amplo, a linguagem mais articulada e ágil. Existem mais personagens, as mulheres aparecem um pouco mais. Contudo, não deixa de ser um mundo fechado, em certo sentido mais fechado do que o das epopéias, e moralmente esquemático. Comentando uma passagem do Yvain, Erich Auerbach faz as seguintes considerações:

É uma paisagem feericamente encantada; estamos envoltos pelo segredo; ao nosso redor há murmúrios e cochichos. Todos os muitos castelos e palácios, lutas e aventuras dos romances corteses, especialmente dos bretões, são do país dos contos de fadas, pois sempre emergem como brotados do chão. A sua relação geográfica com a terra conhecida, as suas bases sociológicas e econômicas ficam sem explicação. Mesmo a sua significação moral ou simbólica só raramente é determinável com alguma certeza. Esta aventura junto à fonte mágica tem algum sentido oculto? Pertence, certamente, àquelas que os cavaleiros da corte de Artur devem empreender, mas em nenhum lugar é dada uma motivação moral da justiça da luta contra o Cavaleiro da Fonte. Em outros episódios dos romances corteses podem ser reconhecidos, às vezes, motivos simbólicos, mitológicos ou religiosos

\footnotetext{
${ }^{40}$ Otto Maria CARPEAUX, História da Literatura Ocidentel, Brasília, Edições do Senado Federal, 2008, v.1, p.176

${ }^{41}$ Idem, p. 177
} 
[...] só que quase nunca os significados podem ser estabelecidos com rigor, pelo menos nos romances corteses propriamente ditos. ${ }^{42}$

Como ressalta o erudito filólogo, essas considerações valem para quase todos os romances corteses. Mesmo mudando de gênero, a paisagem, que acreditamos poder ser chamada de românica, não muda. A lírica dos Cancioneiros medievais comporta uma produção vastíssima escrita ao longo de bastante de tempo. Seria absurdo tentarmos qualificá-la em bloco como românica ou gótica, pois é bem possível que encontremos obras dos dois tipos nela. Em todo caso, é a ela que Bernardo Monteiro de Castro se dirige quando procura pelo que seria a literatura românica. Especificamente, se dirige às cantigas de amor e de amigo, em especial à famosa cantiga de Meendinho, um exemplo muito oportuno. ${ }^{43}$ Realmente, como afirmam alguns críticos, a visão de mundo transmitida por boa parte de lírica medieval ibérica, especialmente pelas cantigas de amigo, nos parece muito afim ao que encontramos nas artes românicas:

Há, por exemplo, em alguns cantares de amigo, uma intimidade espontânea com a natureza que é muito diferente do gosto romântico pela paisagem (como quadro ou reflexo dos sentimentos humanos), e que deve antes relacionar-se com o animismo típico de certa mentalidade primitiva. Dir-se-ia existir uma afinidade mágica entre as pessoas e tudo o que parece mover-se ou transformar-se por uma força interna: a água da fonte e do rio, as ondas do mar, as flores da Primavera ou Verão, os cervos, a luz da alva, a dos olhos. Todas estas coisas participavam ainda de tantas associações, as suas designações evocavam tantas correspondências entre o impulso amoroso e o florescer das árvores, os atos dos animais, os movimentos das coisas mais presentes, que o esquema repetitivo era como o imperceptível e paulatino desenvolvimento de um tema através de modulações que sugerem seus inesgotáveis nexos vitais. ${ }^{44}$

Cremos que foi possível expor algumas características comuns do estilo românico nas artes visuais e encontrar obras literárias nas quais esses elementos estiveram presentes. Acreditamos, portanto, que é possível falar de uma literatura românica com certo rigor. Bernardo Monteiro de Castro, ao tentar definir o que seria a literatura gótica, estudou brevemente o que seria uma literatura românica.

\footnotetext{
${ }^{42}$ Erich AUERBACH, Mimesis: a representação da realidade na literatura ocidental, São Paulo, Perspectiva, 2009, $15^{\text {a }}$ ed., p. 113-114.

${ }^{43}$ Bernardo Monteiro de CASTRO, As Cantigas de Santa Maria: um estilo gótico na lírica ibérica medieval, Niterói, EdUFF, 2006, p.65-68.

${ }^{44}$ Maria BREA LÓPEZ; José Maria DÍAZ DE BUSTAMANTE; Ignácio GONZÁLEZ FERNÁNDEZ, Animales de referencia y animales de significación en la lírica gallegoportuguesa. Boletim de Filologia, T. XXIX, v. II. Lisboa, Centro de Linguística da Universidade de Lisboa, 1984, p.50-51.
} 
Pensamos que essas poucas páginas acrescentam algo ao desenvolvimento dessa importante questão.

\subsection{Símbolo e Alegoria}

Um ponto que consideramos muito importante para a diferenciação entre a literatura românica e a literatura gótica é o papel do simbolismo e da alegoria. Heloisa Guaracy Machado considera que esses dois elementos são essenciais no estudo feito por Bernardo Monteiro de Castro, pois, discutindo os problemas da definição das Cantigas de Santa Maria como obra de literatura gótica afirma o seguinte:

Sua classificação, bastante problemática, reúne duas posturas principais: uma que relaciona o alegórico ao românico, como as de De Bruyne (1959) e de Montoya Martinez (1981), outra que relaciona o alegórico ao gótico, como defende Jacques le Goff (1984). ${ }^{45}$

Não estamos em condição de discutir as posições dos autores acima, mas tendemos a pensar com Jacques Le Goff, pois o que vemos no gótico é a predominância da alegoria e no românico o uso sistemático de símbolos.

A definição desses termos é algo complexa devido aos seus diversos usos. Em todo caso, assumimos a boa formulação dada por Otto Maria Carpeaux: "O símbolo é expressão artística do que é inefável; a alegoria é representação intelectual do que é compreensível." 46 A distinção é simples, mas dela podemos tirar uma série de conclusões muito importantes. Como essa definição é aceita também por psicólogos e antropólogos, podemos nos valer de algumas das suas reflexões. ${ }^{47}$

O símbolo implica uma relação com realidades não plenamente compreendidas, é um modo não analítico de representar essas realidades. A imagem usada para simbolizar - o simbolizante - tem uma relação essencial com a realidade simbolizada. O simbolizante decorre do que é simbolizado, ele depende dessa realidade superior. Quando um escritor usa um símbolo, ele se vale de um registro culturalmente estabelecido (uma imagem tradicional) de uma manifestação de determinada realidade superior para expressar algo dessa realidade.

Quem comanda o processo é a realidade superior através da sua manifestação tida como tradicional. Não se cria um símbolo, apenas se reproduz. A reprodução de um símbolo não é uma ação criativa individual no sentido que entendemos hoje, é a repetição de algo estabelecido pela tradição. Num bestiário, ao falar de uma cobra como símbolo do demônio, o escritor simplesmente retoma uma tradição que associa a cobra ao demônio porque foi dessa maneira que ele se manifestou,

\footnotetext{
${ }^{45}$ Heloisa Guaracy MACHADO, Sobre a concepção medieval e cristã da História nas Cantigas de Santa Maria. In: Ângela Vaz LEÃO (org.), Novas Leituras, Novos Caminhos: Cantigas de Santa Maria de Afonso X, o Sábio, Belo Horizonte, Veredas e Cenários, 2008, p.162-163.

${ }^{46}$ Otto Maria CARPEAUX, História da Literatura Ocidentel, Brasília, Edições do Senado Federal, 2008, v.1, p.197-198.

${ }^{47}$ Marco Heleno BARRETO, Imaginação Simbólica: reflexões introdutórias, São Paulo, Loyola, 2008, p.32.
} 
segundo a tradição cristã. Por essa razão, os símbolos são fortemente atrelados aos mitos.

Já a alegoria implica um domínio pleno tanto sobre o que se fala, quanto sobre a imagem da qual se serve para fazer a alegoria. Fazer uma alegoria implica ter conhecimento de um conceito abstrato e ter conhecimento de seres do mundo material que tenham condições de representar esse conceito. Implica uma série de diferenciações. Primeiramente devemos notar que aquilo que se alegoriza - aquilo que se representa - é um ente abstrato, uma idéia, logo, uma criação humana. Além disso, usa-se algum ser para representar essa idéia. A escolha desse ser não é vista como algo determinado pelo que é alegorizado, não há uma implicação de um em outro. $\mathrm{O}$ que há é uma escolha racional de certos elementos materiais para formar a representação de uma idéia. A alegoria implica, portanto, uma visão onde o mundo e seus seres têm certa autonomia. Quem comanda o processo é o homem, digamos até, o indivíduo que cria a alegoria.

O símbolo, como vimos, tem um caráter sagrado, tradicional e coletivo. A alegoria é mais ligada à criação individual, ao especulativo. Tanto é assim que sempre se fala em simbolismo religioso, em simbolismo sagrado e só muito raramente em alegoria religiosa ou alegorismo sacro.

Essas reflexões se harmonizam com a opinião de Erich Auerbach, pois ele aponta que "a visão alegórica, cujo modelo são os autores pagãos ou não inteiramente cristãos da antiguidade tardia, tende a aparecer onde influências antigas, pagãs ou fortemente secularizadas são dominantes". ${ }^{48}$ Aqui não devemos entender secularizado como sinônimo de não-religioso, mas como de não clerical, não monástico. Num mundo com o do século XIII, uma obra religiosa como as Cantigas de Santa Maria pode ser considerada, e o é por alguns críticos, uma obra, em certo sentido, secular. Portanto, segundo Auerbach, a alegoria aparece onde há maior presença do elemento racional, em detrimento do elemento místico próprio da cultura monacal que dominou a Europa até o século XII. Que o gótico apresenta características mais racionais do que o românico é uma posição comum entre os estudiosos. Cremos ser mais acertado, portanto, relacionar a alegoria ao gótico do que ao românico.

Essa posição poderia ser reforçada por um estudo dos símbolos e das alegorias na literatura medieval. Por enquanto, podemos apenas observar que, segundo os estudiosos, a alegoria tende a aparecer mais na época do gótico e não do românico. O conhecido Roman de la Rose, um romance todo baseado em alegorias, foi composto no período do gótico, e não saberíamos apontar uma obra do período românico que também fosse toda alegórica. ${ }^{49}$

Apesar de não dispormos de um estudo completo sobre os símbolos e as alegorias nas Cantigas de Santa Maria, podemos recapitular alguns dados apresentados na parte anterior. No nosso estudo sobre os animais pudemos observar que na quase totalidade dos casos eles não aparecem nem como símbolos nem

\footnotetext{
${ }^{48}$ Erich AUERBACH, Mimesis: a representação da realidade na literatura ocidental, São Paulo, Perspectiva, 2009, $15^{\text {a }}$ ed., p. 54.

${ }^{49}$ Otto Maria CARPEAUX, História da Literatura Ocidentel, Brasília, Edições do Senado Federal, 2008, v.1, p.276.
} 
como alegorias, mas como animais simplesmente. Nos poucos casos onde vemos animais exercer um papel imagético, eles aparecem, no nosso entender, como alegorias e não como símbolos.

Cremos que novas investigações são necessárias para demarcarmos quais obras são da literatura gótica e quais seriam da literatura românica. Já comentamos nossa impressão sobre essa última; quanto à literatura gótica, além das Cantigas de Santa Maria, devem estar sob essa classificação as obras de alguns importantes escritores do século XIII e XIV como Gonzalo de Berceo e Dante. Só a pesquisa futura poderá confirmar esses nomes e dar-lhes a companhia de, acreditamos, muitos dos seus colegas de ofício.

\section{O Gótico e a Ciência}

Estamos nos último estágio de nossa pesquisa. Retomemos o que foi feito até agora. Começamos estudando como os animais foram usados com símbolos teológicos e morais. Em seguida, analisando as Cantigas de Santa Maria, descobrimos que nessa obra medieval o simbolismo animal é de raro uso, quase inexistente. No terceiro momento tentamos explicar os motivos do pouco uso de elementos simbólicos na obra de Dom Afonso X. Procuramos provar que as Cantigas de Santa Maria teriam esse caráter realista por ser uma obra da literatura gótica.

Agora pretendemos defender outra hipótese: a visão gótica da realidade, que se encontra presente nas Cantigas de Santa Maria, propiciou as condições para a investigação científica da natureza. Mais ainda, em alguma medida, é a própria literatura um fator que colaborou para a existência da ciência natural. Não temos a pretensão de provar esses pontos nessa parte final do artigo, apenas alinhavar alguns elementos que indicam ser esse um caminho possível.

O debate sobre natureza do conhecimento científico data dos albores da filosofia e no século XX se espraiou para outra área de reflexão como a Sociologia e a História. Se as posições apresentadas nos últimos vinte e quatro séculos de reflexão são extremamente variadas, é possível afirmar que, pelo menos entre os divulgadores que formaram a imagem pública da ciência, o que prevaleceu na modernidade foi uma visão cientificista da ciência. Tal visão concedia à ciência natural um posto único e separado dos demais conhecimentos humanos e do desenvolvimento social.

Apesar de contestada por grandes cientistas e filósofos durante alguns séculos, essa visão se impôs graças a pensadores menores, como Voltaire, Haeckel e seus muitos seguidores ainda menos importantes, que compensavam o pouco valor científico de suas obras com um palavreado quase infinito.

Curiosamente, a História da Ciência teve importante papel na confirmação dessa visão vulgar da ciência. As primeiras obras históricas sobre a ciência foram escritas no século XVII, por cientistas. Os meios científicos da época eram permeados pela ideia do progresso constante e necessário do espírito humano e a história escrita nesse meio era um reflexo fiel de tal concepção. Essas histórias legavam ao esquecimento os eventos que não fossem considerados bem sucedidos, aqueles incômodos fatos que testemunhavam que os sucessos são acompanhados de 
fracassos e que não seguem uma lógica predeterminada. Faziam um verdadeiro filtro ideológico, registrando apenas os sucessos, racionalizando o processo histórico e dando uma coerência ao desenvolvimento das ciências que, na realidade, elas nunca possuíram.

Esse modo de reconstrução histórica da ciência teve um longo percurso. Foi praticado por François Guizot, primeiro catedrático de História da Ciência, se manteve predominante até meados do século XX e, em determinados meios, até mesmo no século XXI, pois é o tipo de história ainda presente nos manuais de ciências naturais e nas obras de divulgação científica. ${ }^{50}$

Além disso, a filosofia da ciência da primeira metade do século XX, bastante marcada pela neopositivismo, contribuiu muito para a visão de uma ciência absolutamente isolada de outras áreas do conhecimento humano.

Esse artigo não seria o local apropriado para deslindarmos os diversos problemas envolvidos com essa visão neopositivista da ciência. Apenas declaramos que a visão de ciência que adotamos é bastante diversa por considerar uma multiplicidade de fatores na formação da ciência. Um físico e matemático experimentado como Hermann Bondi afirmou que talvez "uma boa parcela da física mais avançada esteja implícita naquela física básica que aprendemos nos primeiros três anos de nossas vidas" ${ }^{\text {} 51}$ Uma afirmação como essa nos faz pensar que algo da ciência madura poderia estar na linguagem, na teologia, nas artes e em outras manifestações culturais.

A aceitação dessa visão encontra diversas dificuldades, bem sabemos, tanto de caráter prático quanto teórico. A historiografia e a filosofia da ciência de cunho cientificista tiveram uma ampla divulgação, de forma que muitos acreditam nesse divórcio entre a ciência e os demais saberes. No campo mais prático essa divisão se fortalece cotidianamente pelo linguajar usado em muitas ciências.

Hermann Bondi já afirmava que a visão corrente que muitos têm da ciência como algo absolutamente apartado de outras atividades e saberes seria alimentada especialmente pela linguagem obscura dos cientistas. ${ }^{52}$ Linguagem que é especialmente construída para passar a impressão de que a ciência é uma atividade completamente impessoal, maquinal, quantificada e que obedece a uma necessidade lógica indeclinável. Essa linguagem é feita para parecer que o que foi descoberto não poderia deixar de sê-lo, não importando nenhum fator que não estivesse previsto nos procedimentos metodológicos usados. ${ }^{53}$

Além desse problema prático, posições teóricas das mais diversas, como já aludimos, contribuíram para essa crença no completo isolamento da ciência. Charles Percy Snow chegou ao ponto de afirmar que a ciência e as humanidades constituíam duas culturas separadas e incomunicáveis por toda a história do

\footnotetext{
${ }^{50}$ Carlos Alverez MAIA, História da Ciência, uma história de historiadores ausentes. Rio de Janeiro, EDUERJ, 2013, p.77-84.

${ }^{51}$ Hermann BONDI, Conjetura e Mito na Física, Brasília, UnB, 1985, p.11.

${ }^{52}$ Idem, p. 21.

${ }^{53}$ Paula CONTENÇAS, A Eficácia da Metáfora na Produção da Ciência: o caso da genética, Lisboa, Instituto Piaget, 1999, p.66.
} 
pensamento ocidental. Da mesma forma, Gaston Bachelard procurou descrever esses dois campos do saber como mundos absolutamente separados, igualmente válidos em seus próprios termos, mas sem nenhuma comunicação: "a linguagem dos sonhos não contesta a das equações nem esta penetra no mundo daquela" ${ }^{\text {"5 }}$

Como dissemos, não compartilhamos dessa visão, ela nos parece errada por uma série de motivos, motivos que serão expostos no decorrer do trabalho. Nas páginas seguintes tentaremos mostrar como os mais diversos elementos formaram uma visão de mundo propícia para o desenvolvimento da ciência, além de apontarmos para alguns casos específicos nos quais a arte gótica foi fundamental para o progresso científico.

\subsection{A ciência biológica na Idade Média}

Uma pergunta se impõe antes de estudarmos a influência da visão gótica de mundo sobre o desenvolvimento da ciência biológica na Idade Média. Teria havia um estudo biológico no período medieval? A pergunta não é sem sentido, porque, como veremos, diversos autores negam a existência dessa ciência nesse período. Não é pacífico falarmos da biologia na Idade Média.

Ernst Mayr, conhecido historiador da Biologia, parece duvidar da existência dessa ciência no período medieval:

Em comparação [com a Física], a biologia continuava dormente. Os únicos aspectos da natureza viva a merecerem atenção foram os problemas da medicina humana. É em vão que se procura por tentativas de abordagem dos problemas mais profundos da vida, tão fascinantes para os séculos posteriores e para o pensamento moderno. Tem-se a impressão de que essa falta de interesse era, de alguma forma, ligada à extrema piedade do período, que não permitia questões sobre a criação de Deus. ${ }^{55}$

Segundo Mayr a inexistência ou estagnação da Biologia na Idade Média se deveu ao papel que o cristianismo exercia nas mentes:

A teologia cristã é dominada pelo conceito de criação. O mundo, segundo a Bíblia, é um mundo criado recentemente, e todo o conhecimento sobre o mesmo está contido na palavra revelada. Esse dogma excluía a necessidade, e mesmo a possibilidade, de levantar qualquer questão sobre o "porquê", ou de acolher qualquer pensamento de evolução. O mundo, tendo sido criado por Deus, era, segundo exprimiu mais tarde Leibniz, "o melhor dos mundos possíveis". 56

\footnotetext{
${ }^{54}$ Olavo de CARVALHO, Aristóteles em Nova Perspectiva: introdução à teoria dos quatro discursos, São Paulo, É Realizações, 2006, p.28.

${ }^{55}$ Ernst MAYR, O desenvolvimento do pensamento biológico: diversidade, evolução e herença, Brasília, Editora da Universidade de Brasília, 1998, p.116.

${ }^{56}$ Idem, p.113-114.
} 
Evidente que sua posição é bastante preconceituosa e absolutamente falsa. $\mathrm{O}$ dogma não excluía a possibilidade de se levantar questões. É possível que Mayr desconheça que o método por excelência da reflexão medieval é justamente a disputa de opiniões, inclusive sobre o mundo natural e sua criação. Outro historiador da biologia, Émile Guyénot, não se dá nem ao trabalho de comentar mais longamente sobre a Idade Média, limita-se ao seguinte: "Después del predomínio estéril de la Escolástica, durante los oscuros tiempos de la Edad Media, el Renacimiento abrió a la ciência un camino más fecundo: en efecto, revivió las obras olvidadas de los grandes médicos y naturalistas de la Antiqüedad." ${ }^{57}$ No correr do livro, de modo sistemático, o autor passa diretamente de Aristóteles aos naturalistas dos séculos XVI ou XVII.

Outro historiador da Biologia declara simplesmente que a Idade Média foi um período de retrocesso da ciência. Os homens, por influxo do cristianismo, não mais observavam os fatos e entendiam os questionamentos sobre o mundo natural como demoníacos. ${ }^{58}$

Outros historiadores são menos tendenciosos, em todo caso temos que reconhecer que pouco sabemos sobre biologia medieval e menos ainda sobre a zoologia do período.

Os estudos sobre a ciência no período medieval vêm aumentando, mas o foco dos historiadores parece ser a Física. Vemos isso em diversas obras, mas, para citar um exemplo, notamos que o livro de David Lindberg, The Beginnings of Western Science, dedica apenas quatro das suas quase quinhentas páginas à ciência zoológica. A justificativa para essa pouca representação do conhecimento zoológico é que "the history of medieval zoology has yet to be written..."

Realmente não foi, até onde sabemos. Ao lermos sobre a história das ciências na Idade Média ou os capítulos referentes a esse período nas histórias da Biologia encontramos muito pouco. Aqui não é o lugar, e nem haveria condições, de escrever uma história da zoologia medieval. Somente daremos alguns apontamentos muito espaçados referentes a essa história para podermos dar sequência à nossa reflexão.

Com o fim do império Romano, parte da cultura antiga se abrigou nos mosteiros. Se muitos livros filosóficos e literários sobreviveram, o mesmo não pode ser tido das obras biológicas, bem menos preservadas e conhecidas. A Naturalis Historia de Plínio, o Velho, por exemplo, era conhecida por Beda, mas não por santo Isidoro. ${ }^{60}$

\footnotetext{
${ }^{57}$ Émile GUYÉNOT, Las Ciencias de la Vida en los siglos XVII y XVIII el Concepto de la Evolucion, México D.F., UTEHA, 1956, p.6.

${ }^{58}$ H. R. HAYS, Birds, Beasts and Men: a humanist history of zoology, Baltimore, Penguin Books, 1973, p.38.

${ }^{59}$ David C. LINDBERG, The Beginnings of Western Science: the european scientific tradition in philosophical, religious, and institutional context, prehistory to A.D. 1450, Chicago, Chicago University Press, 2007, p.353.

${ }^{60}$ Alistair Cameron CROMBIE, Historia de la Ciencia: de San Agustín a Galileo, v.1 Siglos VXIII. Madrid, Alianza Editorial, 1987, p.32.
} 
Sem o suporte literário, pouco se estudou, que saibamos, sobre os animais nos inícios da Idade Média.

A reflexão sobre os animais aparece em obras de caráter teológico, como nos comentários ao livro do Gênesis. Algumas ideias interessantes foram formuladas nessa clave teológica, como, por exemplo, a teoria das razões seminais de santo Agostinho que afirmava que Deus havia criado todos os seres, conforme registrado na Sagrada Escritura, mas uns na sua forma atual e completa, como Adão e Eva, e outros apenas nos seus princípios, nas suas razões seminais. Com o tempo esses princípios iriam “desabrochar" transformando-se, assim, nos seres viventes.

Vimos anteriormente que o comportamento dos animais era objeto de interesse, mesmo que fosse com o objetivo de servir de modelo aos homens. Em alguns autores, como em Santo Ambrósio, parece há alguma reflexão teórica sobre o comportamento deles, mas não podemos aquilatar seu valor e sua influência.

Compilações que tratam também dos animais perpassam toda a Idade Média. Umas são mais realistas, como o livro sobre os animais nas Etimologias de santo Isidoro, outras mais influenciadas pelo Fisiólogo. Nessas obras destaca-se o livro Physica de Hildegarda de Bingen, composto por volta de 1150. É uma obra sem pretensões de erudição e não baseada em livros, uma compilação de observações feitas diretamente sobre animais, plantas e minerais que tem por fim mostrar quais são os benefícios que o homem poderia obter deles para sua saúde. ${ }^{61}$ Seu valor se dá mais pelas partes relativas às plantas, que foram muito usadas pelos botânicos alemães até o século XVI. ${ }^{62}$ Com essa obra já vemos o desabrochar, de forma mais clara, do interesse pelo estudo do animal real.

O século XIII viu o apogeu do gótico, da escolástica e também da zoologia medieval. As obras científicas desse século são alimentadas pelas recentes traduções das obras zoológicas de Aristóteles feitas por Miguel Escoto do árabe ao latim entre 1220 e 1235 , a mando de Frederico II. ${ }^{63}$ Um pouco mais tarde essas obras ganharão nova tradução, dessa vez diretamente dos textos gregos, feitas pelo frei dominicano Guilherme de Moerbeck. ${ }^{64}$

Com base em Aristóteles e em outros escritos surge uma das primeiras obras de vulto da zoologia medieval, De Arte Venandi cum Avibus de Frederico II. A obra se destaca pela exatidão das observações e pelo seu espírito crítico. Começa tratando da anatomia e costumes das aves, depois descreve o modo de criar e alimentar os falcões usados nas caças e o adestramento dos cães que lhes acompanham. Termina com a descrição dos muitos tipos de falcões e de aves que eles caçam. ${ }^{65}$ Suas

${ }^{61}$ Erik NORDENSKIÖLD, The history of Biology: a survey, New York, Tudor Publishing Company, 1936, p.78-79.

${ }^{62}$ Lois N. MAGNER, A History of the Life Sciences, New York, Marcel Dekker, 1994, p.78.

63 Sylvain GOUGUEINHEIM, Aristote au Mont Saint-Michael: les racines grecques de L'Europe chrétienne, Paris, Seuil, 2008, p.104.

${ }^{64}$ Alistair Cameron CROMBIE, Historia de la Ciencia: de San Agustín a Galileo, v.1 Siglos VXIII. Madrid, Alianza Editorial, 1987, p.52.

${ }^{65}$ Idem, p. 132. 
observações sobre o voo dos pássaros não foram superadas, na opinião de Konrad Lorenz, até o século XX. ${ }^{66}$ Mesmo se servindo de Aristóteles como uma de suas fontes de informação, não recusava a criticá-lo quando não via motivos para acreditar em suas asserções. As ilustrações que acompanhavam seu manuscrito representam mais de 900 aves distintas com um naturalismo surpreendente, indo até os detalhes da penugem. É possível que ele tenha mantido dois criadouros de animais selvagens com o objetivo de realizar estudos para um livro, que infelizmente não foi escrito, sobre mamíferos.

No século XIII as enciclopédias medievais ganham um caráter mais realista, o mundo natural passou a ser observado e descrito com maior precisão. Comentaremos algumas obras, apenas para documentar algo dessa nova fase da história da Biologia.

Tomás de Cantimpré escreveu seu Liber de Natura Rerum entre 1233 e 1248. Nele o frade dominicano estuda diversas espécies seguindo a literatura tradicional sobre a matéria, mas não se limita a repetir o que estava consignado nos livros. Sai ao campo e pesquisa por conta própria alguns animais, fornecendo as primeiras descrições científicas de certos seres vivos próprio da sua região, a Flandres. $\mathrm{O}$ livro fez bastante sucesso, foi traduzido para o holandês por Jacob van Maerlant entre 1265 e 1269, e para o alto médio-alemão por volta de 1350 por Conrad von Megenerg. Essa última tradução não era uma cópia exata do livro latino, mas uma versão ampliada e melhorada. ${ }^{67}$

Outro dominicano, Vicente de Beauvais, também escreveu sobre os animais. Sua obra chamada Speculum Maius dedica boa parte, o chamado Speculum Naturale, ao estudo da natureza e dos seus animais. Seu intento era integrar os saberes naturais da época com a teologia cristã. Além de descrições anatômicas dos animais, apresentava-os como fonte de medicamentos. Teve grande difusão na sua época e posteriormente. Com a invenção da prensa foi lido nas universidades nos séculos XV e XVI. ${ }^{68}$ Dom Afonso usou de uma parte do Speculum Maius, o Speculum historiale, como fontes de suas Cantigas de Santa Maria. ${ }^{69}$

Em Castela temos o franciscano Juan Gil de Zamora que deixou inacabada sua Historia naturalis. $\mathrm{O}$ autor tinha planejado uma obra muito extensa, organizada em ordem alfabética, que descreveria todo o mundo natural. Infelizmente, só conseguiu redigir os verbetes iniciados com a letra $\mathrm{A}$, mesmo assim, a obra atingiu considerável extensão. Nela são consultadas tanto as obras clássicas como as de

\footnotetext{
${ }^{66}$ H. R. HAYS, Birds, Beasts and Men: a humanist history of zoology, Baltimore, Penguin Books, 1973, p.49.

${ }^{67}$ Ilse JAHN, El periodo cristiano-latino del feudalismo europeo, In Ilse JAHN; Rölf LOTHER; Konrad SENGLAUB (org.), Historia de la Biologia: teorías, métodos, instituiciones y biografias breves, Barcelona, Editorial Labor, 1990, p.122-123.

${ }^{68}$ Idem, p. 122.

${ }^{69}$ Matilde Lopéz SERRANO, Cantigas de Santa Maria de Alfonso X el Sabio, Rey de Castilla, Madrid, Editorial Patrimonio Nacional, 1987, p.15.
} 
seus contemporâneos. ${ }^{70}$ A entrada De Anathomia, editada recentemente, se estende por vinte páginas e é dividida em quinze partes, dentre as quais se encontram uma dedicada à anatomia do cérebro e dos nervos sensíveis, outra para os "membros nutritivos", ou seja, boca, língua, estômago, intestinos..., uma para os "membros espirituais" como o coração e o pulmão.

Escreveu também obras médicas como um tratado Contra Venana et animalia venenosa. ${ }^{71}$ É sabido que foi um colaborador de dom Afonso X, ajudando a recolher histórias sobre a Virgem Maria que, posteriormente, seriam poetizadas. Não seria de espantar que as concepção sobre a natureza desse franciscano fosse semelhantes às de Dom Afonso $\mathrm{X}$.

Uma produção científica mais ampla, rigorosa e de maior influência é a de santo Alberto Magno, também dominicano. Alberto Magno foi um gênio universal, escreveu sobre filosofia, teologia, botânica, mineralogia, geografia e zoologia. Sua principal obra sobre os animais, De Animalibus, é composta de 26 livros. Desses, dezenove são paráfrases comentadas das obras zoológicas de Aristóteles e o são restante investigações pessoais. ${ }^{72}$ Não devemos menosprezar a parte onde comenta o grande filósofo grego, pois nela o pensador medieval não teme fazer correções e reparos baseados nas suas próprias pesquisas e no recolheu em outros autores. ${ }^{73}$

Os sete livros com consignam a pesquisa original de Alberto Magno são de muito valor. Nele encontramos acuradas descrições de animais ainda não registrados na literatura científica e importantes estudos teóricos. $\mathrm{Na}$ zoologia teórica sua principal contribuição teria sido a sistematização e aperfeiçoamento da classificação dos seres vivos de Aristóteles e a divisão dos peixes em dez gêneros. ${ }^{74}$ No campo da zoologia descritiva, devemos salientar que o sábio dominicano conseguiu determinar como se dá a mudança dos membros nos crustáceos e qual é o papel do sistema nervoso central e periférico nesses animais. Desenvolveu bastante a embriologia. Fazendo estudos com ovos de galinha conseguiu descrever muito bem o desenvolvimento do ovo até seu nascimento e descobriu como se dá a nutrição fetal. Estudou o desenvolvimento dos insetos, corrigindo algumas posições de Aristóteles, mostrando as diversas fases, do ovo até o animal adulto passando pela crisálida. Dissecou grilos, formigas e fez muitas observações sobre os pássaros e mamíferos. ${ }^{75}$

\footnotetext{
${ }^{70}$ Ilse JAHN, El período cristiano-latino del feudalismo europeo, In Ilse JAHN; Rölf LOTHER; Konrad SENGLAUB (org.), Historia de la Biologia: teorías, métodos, instituiciones y biografias breves, Barcelona, Editorial Labor, 1990, p.123.

${ }^{71}$ Horacio SANTIAGO-OTERO, La cultura em la Edad Media Hispana (1100-1470), Lisboa, Edições Colibri, 1996, p.35.

${ }^{72}$ Alistair Cameron CROMBIE, Historia de la Ciencia: de San Agustín a Galileo, v.1 Siglos VXIII. Madrid, Alianza Editorial, 1987, p.140.

${ }^{73}$ Josef PIEPER, Scholasticism: personalities and problems of medieval philosophy, New YorkToronto, McGraw-Hill Book Company, 1964, p.114.

${ }^{74}$ Alistair Cameron CROMBIE, Historia de la Ciencia: de San Agustín a Galileo, v.1 Siglos VXIII. Madrid, Alianza Editorial, 1987, p.144-145.

${ }^{75}$ Idem, p. 143-144.
} 
Como podemos ver, o grande naturalista medieval não se limitava a leitura dos livros e á especulação filosófica. Defendeu esse procedimento, inovador e tão importante para o desenvolvimento da ciência natural, afirmando que a filosofia não era suficiente: "Porque a Filosofia não pode tratar de coisas concretas... Não podemos fazer silogismos sobre naturezas concretas, das quais só a experiência (experimentum) dá certeza. ${ }^{76}$

Devemos notar que Alberto Magno fez escola, o primeiro livro sobre animais escrito em alemão foi composto por um seu seguidor e é bastante baseado nos seus escritos. Além disso, o interesse por sua obra não diminuiu com sua morte. Com a invenção da impressa seus livros sobre os animais ganharam mais leitores; foram impressos em Roma (1478), em Mântua (1479), em Veneza (1495 e 1519) e em Lyon numa data já bastante avançada (1651), o que mostra que fora considerado um livro importante por quase quatrocentos anos. Foi feita uma tradução em alemão, publicada em 1545 (Fig.4).

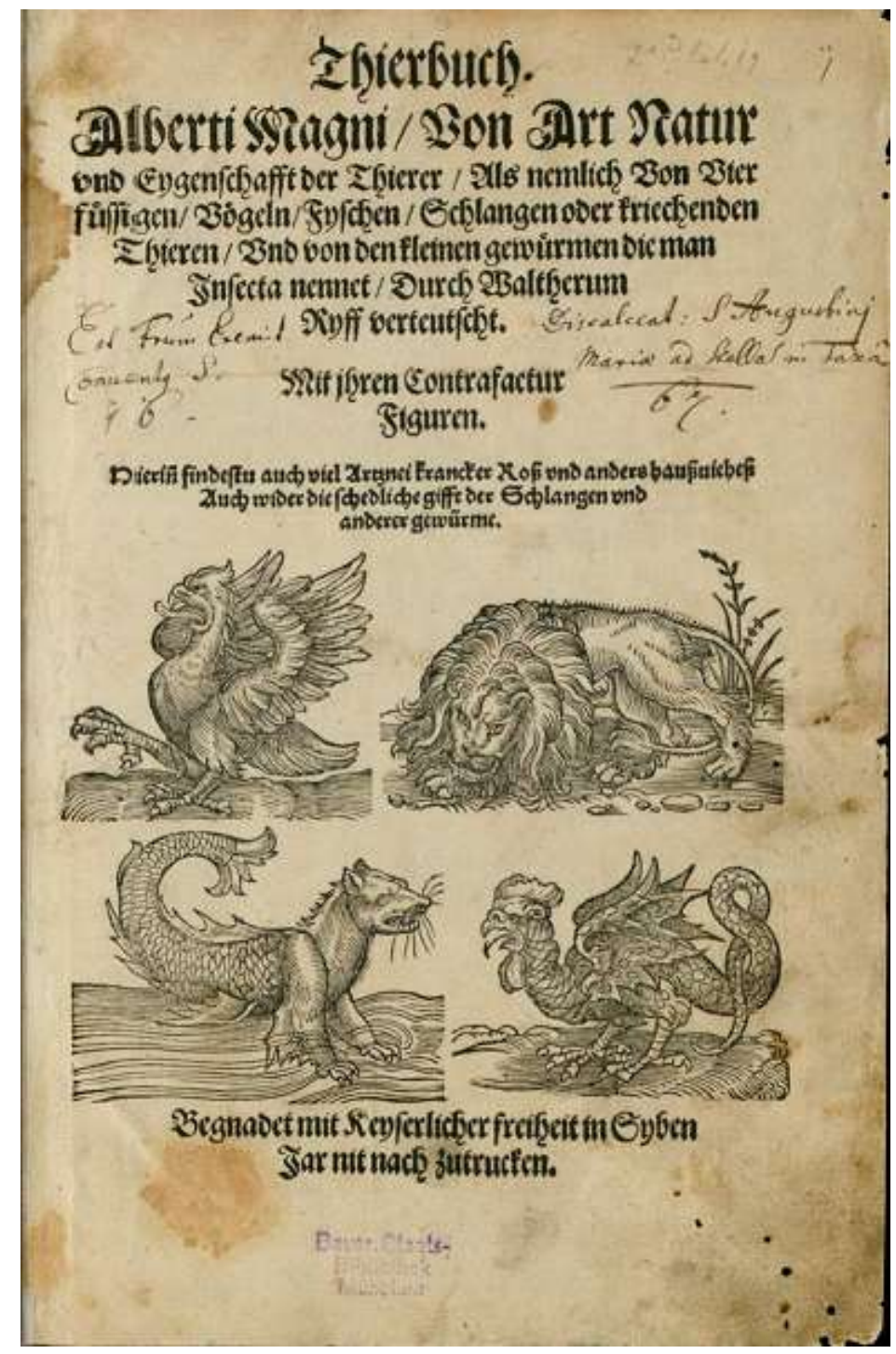

Fig.4. Thierbuch (De Animalibus) de Alberto Magno, 1545, Frankfort am Main Imagem tomada de Wikimedia Commons (Última consulta: 06/01/2016)

${ }^{76}$ Apud Ibidem, p.137. 
O livro teve tal difusão, entre outros motivos, porque foi adotado em muitas universidades, tendo, portanto, muitos leitores. ${ }^{77}$ Um deles, Conrad Gesner, considerado um dos pais da moderna Zoologia, cita-o várias vezes nas suas obras. Não só cita, também segue alguns de seus procedimentos. ${ }^{78}$ Vemos assim que a zoologia medieval, por modesta que tenha sido, fecunda em alguma medida os trabalhos da modernidade.

Seria preciso analisar o valor científico e a possível influência dos tratados sobre caça. Neles é possível encontrar descrições de aves, cães e cavalos, bem como do seu comportamento e das doenças que poderiam sofrer. Apesar de certo substrato literário, esses textos se baseam, em muitos casos, na experiência dos criadores, o que lhes confere um interesse especial. Os aspectos da fisiologia, do comportamento e das patologias animais são os mais interessantes entre os apresentados nessa literatura. Não conhecemos estudos que indiquem se, em algum momento, esses conhecimentos foram utilizados por naturalistas com perspectivas mais científicas. Nesse sentido, apenas recordamos a existência de indícios de que Buffon considerava algumas partes do Livre de Chasse (1388) de Gaston Phebus dignas de atenção.

Outro fator importante para uma futura história da biologia medieval é a investigação dos textos médicos. Em alguns deles é possível encontrar material sobre os animais, não só porque há o entendimento que o homem é também um animal, mas porque as dissecações humanas nas faculdades de Medicina só começaram no final do século XIII e, até então, eram feitas em animais. ${ }^{79}$ É certo que muito desse conhecimento permaneceu no nível tácito, não sendo registrado em livros e dificultando, mas não impossibilitando, o trabalho dos historiadores. $\mathrm{O}$ uso médico das plantas certamente levou à aquisição de conhecimentos em Botânica que não podem ser desprezados.

Além disso, para completar esse desfalcado panorama da investigação biológica medieval, seria necessário ter em conta um considerável número de autores ainda carentes de estudos e, até mesmo, da edição dos seus livros. Para ficarmos apenas na região ibérica, basta lembrar que as obras científicas de Pedro Galego, confessor de Dom Afonso X e primeiro Bispo de Cartagena, só foram editadas no ano 2000, da mesma forma que a grande obra de Pedro Hispano, Questiones super libro "De Animalibus" Aristotelis, só foi editada em 2009.

Traçada essa brevíssima e lacunar história da zoologia medieval, o que poderemos concluir? Devemos observar que esse interesse pelo mundo natural se manifesta antes da redescoberta das obras zoológicas de Aristóteles. Já no século XII, como vimos, santa Hidelgarda de Bingen fazia suas observações da natureza.

\footnotetext{
${ }^{77}$ Nicolae BOTNARIUC; Ilse JAHN, La biología en la época del Renacimiento y del capitalismo manufacturero. In Ilse JAHN; Rölf LOTHER; Konrad SENGLAUB, Historia de la Biologia: teorías, métodos, instituiciones y biografias breves, Barcelona, Editorial Labor, 1990, p.165.

${ }^{78}$ Idem, p. 167.

${ }^{79}$ Renate BLUMENFELD-KOSINSKI, Not of Woman Born: Representations of Caesarean Birth in Medieval and Renaissance Culture, Ithaca, Cornel University Press, 1991, p.30.
} 
E, também antes do conhecimento das obras de Aristóteles sobre os animais, vemos esculpidos nas novas catedrais góticas muitos temas da natureza. Aliás, é esse interesse na natureza real que nos faz entender porque os pensadores medievais se interessaram pela obra do Estagirita. Numa sociedade que pouco se importasse com a natureza dos animais e que tivesse seus olhos voltados somente para as alturas metafísicas, sua obra nem mesmo seria traduzida e, se fosse, pouco interesse despertaria.

Edward Grant, especialista em história da ciência no período medieval, lembra da existência de alguns filósofos interessados em temas matemáticos e científicos no período anterior ao século XII, mas afirma que foi nesse século que a mentalidade europeia sofreu uma forte mudança no sentido de buscar cada vez mais compreender o mundo natural. Em suas palavras:

No entanto, não foi o nível de progresso científico o factor essencial para as alterações intelectuais verificadas no século XII. De algum modo, deu-se uma notável alteração na atitude para com as autoridades tradicionais e para com a própria natureza. [...] a ideia de que Deus era a casa directa e imediata de tudo cedeu perante uma interpretação do mundo que partia do princípio de que os objetos naturais eram susceptíveis de atuar diretamente uns sobre os outros. Deus conferira à natureza o poder e a capacidade para ser a causa de todas as coisas. Fizera dela uma entidade auto-operante. A natureza, ou o cosmo, era assim objetivada e concebida como um todo harmonioso, regido por leis, bem ordenado e auto-suficiente, que podia ser investigado pela inteligência humana. Conceitualmente, o mundo foi transformado, de uma entidade imprevisível e fortuita, num mecanismo funcionando com regularidade, ou machina como era chamado com frequência no século XII. ${ }^{80}$

Além de registrar o surgimento dessa nova concepção de natureza no século XII, chamamos atenção para a afirmação do autor de que essa mudança no modo de ver o universo não se deu por nenhum progresso científico. Essa constatação, encontrada em diversos outros autores, nos leva a buscar fora do campo estritamente científico os elementos que contribuíram para essa nova visão da natureza. Acreditamos que a arte gótica pode ser considerada como um dos elementos mais importantes na criação dessa visão de mundo que possibilita a existência da ciência.

Daqui em diante, quando falarmos de gótico, estaremos pensando tanto nas artes visuais, quanto na literatura, em harmonia com o que defendemos anteriormente sobre a existência de uma literatura gótica. Vale a pena lembrar que, contra alguns que diminuem a valor cognitivo da literatura que a diferença entre poetas e filósofos, por vezes, é tênue. Para ficarmos com exemplos medievais, lembremos que no século XII Bernardo Silvestre colocou em versos as doutrinas filosóficas neoplatônicas da Escola de Chartres na sua Cosmographia e fez comentários

${ }^{80}$ Edward GRANT, Os Fundamentos da Ciência Moderna da Idade Média, Porto, Porto Editora, 2002, p.24.

Eikón Imago 9 (2016/1) ISSN-e 2254-8718 
filosóficos aos seis primeiros livros da Eneida de Virgilio. ${ }^{81}$ São Tomás de Aquino, que é tido como o maior filósofo medieval, é considerado por Otto Maria Carpeaux como o "maior poeta litúrgico" da Igreja Católica. ${ }^{82}$

Isso mostra que nosso rei poeta, bem como todos os outros escritores do período, também poderia exprimir nas suas Cantigas de Santa Maria concepções bastante coerentes sobre a natureza criada e não apenas impressões estéticas mais ou menos aleatórias. Vimos a grande importância de Aristóteles para a biologia medieval, mas não só para a biologia. É certo que alguns escritores de ficção também conheciam algo da obra do Estagirita. Dom Afonso, pelo menos em uma ocasião, se declarou um aristotélico. No prefácio de sua obra sobre as pedras, o Lapidário, afirma o seguinte:

Aristóteles, fue más cumplido que los otros filósofos y el que más naturalmente mostro todas las cosas por razón verdadera y las hizo entender cumplidamente según son." ${ }^{83}$

Não seria surpreendente, em vista do grande movimento aristotélico do século XIII, que Dom Afonso e outros escritores tenham conhecido as obras naturais do grande filósofo grego. Em todo caso, como ficará claro posteriormente, acreditamos que, pelo menos num primeiro momento, são os artistas que conduzem o pensamento medieval em direção à natureza, eles são os desbravadores que preparam caminho para Aristóteles, mesmo que depois recebam sua influência.

\subsection{Cristianismo e Ciência}

A visão gótica do mundo é uma visão teológica, uma visão cristã. Para muitos autores, mesmo os mais recentes, essa visão cristã seria um problema para o desenvolvimento da ciência. Ernst Mayr, que citamos a pouco, é apenas mais um de uma infinidade de escritores que afirmou a existência de um confronto irremediável entre uma concepção religiosa do mundo e o desenvolvimento científico. John William Draper, autor de History of the Conflict between Religion and Science, pode ter sido um dos mais afamados, mas também foi apenas um numa longa série de autores mais ou menos influentes.

Nietzsche, que não era nada positivista e nem cientificista, afirmou: "A história e as ciências da natureza foram necessárias contra a Idade Média: o saber contra a crença." ${ }^{\nexists 4}$ Essa mesma Idade Média, por ser uma época onde os principais pensadores eram religiosos, é acusada de não promover os valores apropriados para o florescimento das ciências, de ser "aquele mundo subserviente e sangrento [que] não suportava nem a independência nem a tolerância." ${ }^{.85}$

${ }^{81}$ Édouard JEAUNEAU, A Filosofia Medieval, Lisboa, Edições 70, 1986, p.52.

${ }^{82}$ Otto Maria CARPEAUX, História da Literatura Ocidentel, Brasília, Edições do Senado Federal, 2008, v.1, p.169.

${ }^{83}$ Aristóteles foi mais perfeito que os outros filósofos e foi o que mais naturalmente demostrou todas as coisas por razão verdadeira e as fez entender plenamente como realmente são. (ALFONSO X, Lapidario, Madrid, Editorial Castalia, 1968, p.9.)

${ }^{84}$ Friedrich NIETZSCHE, O livro do filósofo, Porto, Editora Rés, 1984, p.31.

${ }^{85}$ Jacob BRONOWSKI, Ciência e valores humanos, Belo Horizonte, Itatiaia, 1979, p.74. 
Que a crença religiosa e a pesquisa científica possam coexistir é algo simples de se constatar. Não é preciso nem consultar a vasta, e cada vez maior, bibliografia existente sobre o assunto. Basta observar a presença constante de religiosos atuantes nos mais diversos campos científicos, em diversas épocas e regiões. Os nomes mais famosos certamente aparecerão na mente do leitor inteirado do assunto, mas é preciso lembrar que um grupo enorme de pesquisadores nos últimos oito séculos adotava uma visão religiosa do mundo. Por vezes essa visão foi determinante na carreira científica. Por considerarem a natureza uma criação de Deus espelhava de alguma forma suas infinitas qualidades, muitos homens passaram a ter um interesse "sobrenatural" em formigas, ossos, membranas, folhas e os mais variados objetos passíveis de uma investigação científica.

Para darmos um exemplo fora do período medieval, lembramos do estudo de Éric Baratay ${ }^{86}$ (1995) que mostra como o estudo da zoologia foi promovido e conduzido pelo clero católico francês no século XVIII por se tratar de "une science au service de Dieu". Da mesma forma, seria possível tratar da enorme contribuição dos jesuítas à sismologia, à astronomia, à entomologia e aos mais variados campos científicos.

No século XIII, Vincent de Beauvais fez uma afirmação que poderia ser encontrada na pena de naturalistas dos séculos posteriores:

Estou movido por uma doçura espiritual até o Criador e Governador deste mundo, porque Lhe sigo com a maior veneração e reverência quando contemplo a magnitude, a beleza e a permanência de sua criação" ${ }^{\text {"87 }}$

Esse interesse pela natureza como imagem do Criador é, certamente, uma das maiores contribuições da religião cristã à ciência, mas existem relações profícuas entre esses dois campos que são regidas por necessidades mais práticas e mais surpreendentes.

Renate Blumenfeld-Kosinski mostrou que a crença católica no batismo como meio necessário para a salvação foi determinante no desenvolvimento da cirurgia e da obstetricia na Idade Média. ${ }^{88}$ A necessidade de se retirar a criança do ventre de sua mãe para batizá-la e assim lhe abrir a porta do céu, necessidade espiritual reforçada e propagada pelos papas, levou ao desenvolvimento e ao uso mais constante de técnicas de parto cesariano desconhecidas da antiguidade e da civilização islámica coeva. Da mesma forma, indo para o campo da astronomia, a necessidade de comemorar a ressureição de Cristo no dia correto foi um dos elementos que levaram ao uso de igrejas católicas como observatorios solares.

\footnotetext{
${ }^{86}$ Éric BARATAY, Zoologie et Église catholique dans la France du XVIIIe siècle (1670-1840): une science au service de Dieu, Revue d'Histoire des Sciences, 1995, vol.48, n.3, p.241-265.

${ }^{87}$ Apud Alistair Cameron CROMBIE, Historia de la Ciencia: de San Agustín a Galileo, v.1 Siglos V-XIII. Madrid, Alianza Editorial, 1987, p.159.

${ }^{88}$ Renate BLUMENFELD-KOSINSKI. Not of Woman Born: Representations of Caesarean Birth in Medieval and Renaissance Culture, Ithaca, Cornel University Press, 1991, p.28.
} 
Esses exemplos mostram como as relações entre a ciencia e a religião são complexas e permeadas por uma série de variáveis muitas vezes não previsíveis.

Mas há algo mais profundo. Toda ciência pressupõe certa ordem no mundo. Qualquer pesquisa científica pressupõe a constância da natureza, pressupõe que as forças e as matérias de seu experimento não serão alteradas sem uma causa ou se comportarão de forma totalmente diversa nas mesmas condições. Todo cientista pressupõe que a natureza se comportará de forma estável. Ao estudar determinado ser ou fenômeno, pressupõe que as "leis" da natureza continuarão as mesmas do começo ao fim de seu estudo.

Mas, qual é a garantia que ele tem disso? É possível provar cientificamente que uma lei natural sempre foi e sempre será a mesma? É possível fazer uma experiência relativa a isso? Evidente que não. Essa é uma constatação inegável que foi expressa nos seguintes termos pelo filosofo polonês Leszek Kolakowski:

a aceitação do mundo como um cosmo ordenado pela Divindade, que a dado um sentido ao todo, não é auto-contraditória nem incoerente com o conhecimento empírico e, contudo, nunca pode ser o resultado de tal conhecimento, por muito extenso que ele seja. ${ }^{89}$

Fundamentando toda a ciência existe a suposição de que o universo é estável, que suas leis não mudam, que é um todo ordenado e que essa ordem não é subvertida a todo tempo. Outro importante filósofo do século XX, Alfred North Whitehead, já apresentava reflexões dessa natureza na primeira metade do século, mas procurava também suas raízes históricas.

Whitehead acreditava que a crença na estabilidade do universo teria original na Idade Média. Nesse sentido, afirmava que a principal contribuição medieval à ciência seria a "crença inexpugnável de que todo evento circunstanciado pode ser relacionada com seus antecedentes de um mondo perfeitamente preciso, demonstrando princípios gerais. ${ }^{90 "}$ "Essa crença basilar da ciência teria sua origem na ideia que então se tinha de Deus:

A origem dessa crença se encontraria na ideia católica de Deus formulada pela teologia medieval. Essa concepção seria única no campo religioso por combinar a racionalidade grega e a ideia de um Deus pessoal dos judeus. Na Ásia, as concepções de Deus eram de um ser ou muito arbitrário ou muito impessoal para que tais ideias tivessem grande efeito sobre os hábitos instintivos da mente. Todo evento circunstanciado poderia ser devido à sanção de um déspota irracional ou poderia emanar de alguma origem das coisas impessoal e inescrutável. Não havia a mesma confiança como na racionalidade inteligível de um ser pessoal. Não estou defendendo que a confiança europeia na investigação da natureza fosse logicamente justificada até mesmo pela

\footnotetext{
${ }^{89}$ Leszek KOLAKOWSKI, Si Dios no existe...: sobre Dios, el diablo, el pecado y otras preocupaciones de la llamada filosofia de la religión, Madrid, Editorial Tecnos, 1985, p.54-55.

${ }^{90}$ Alfred North WHITEHEAD, Ciência e o mundo moderno. São Paulo: Paulus, 2006, p.27. 
nossa teologia. Meu único objetivo é entender como isso começou. Minha explicação é que a fé na possibilidade da ciência, produzida anteriormente para o desenvolvimento da teoria científica moderna, é um derivado inconsciente da teologia medieval. ${ }^{91}$

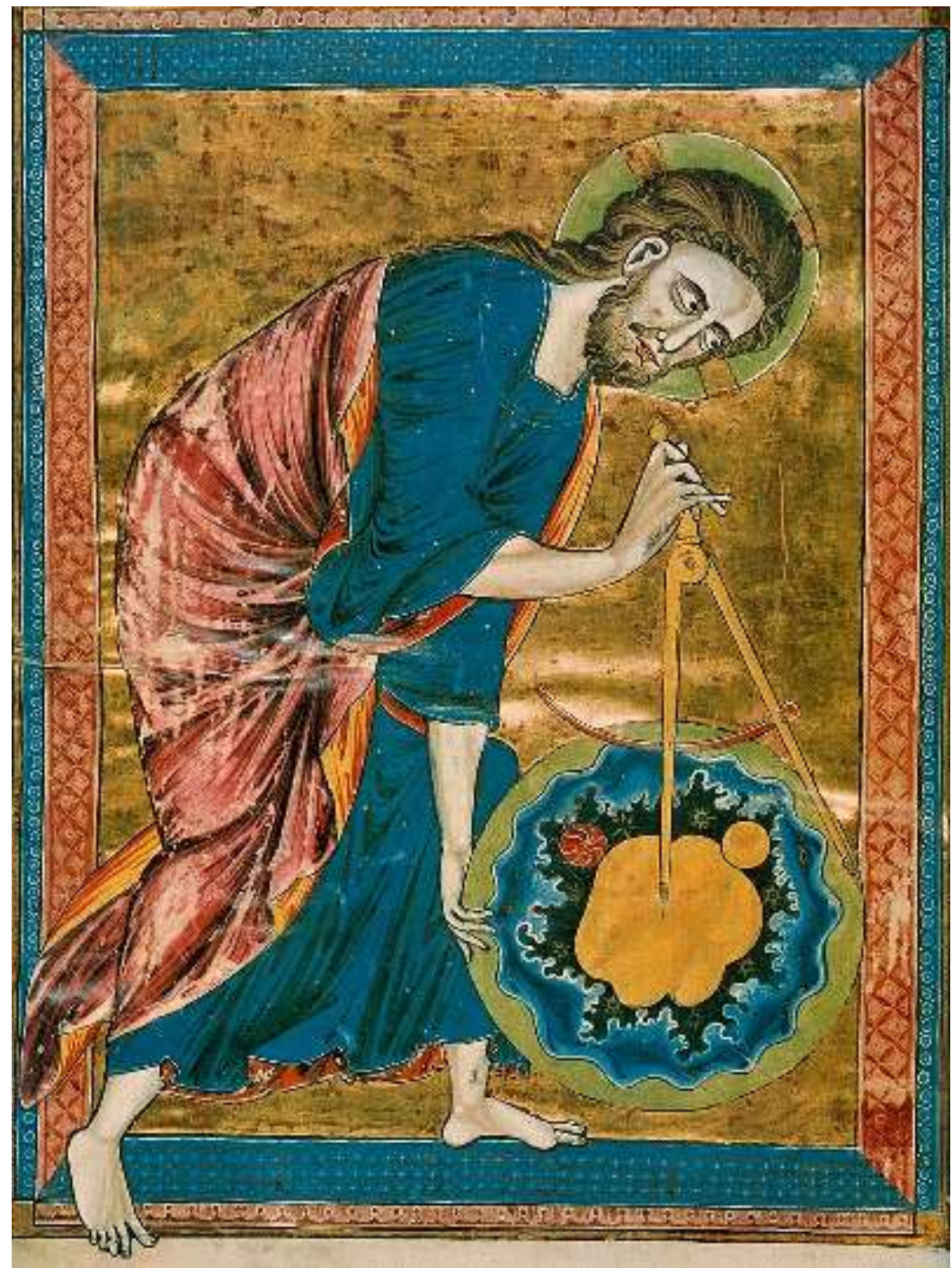

Fig.5. Deus ordenando o universo, 1215-1230, França. Bíblia Moralizada de Viena 2554 f.1v, Biblioteca Nacional da Áutria. Imagem tomada de Wikimedia Commons (Última consulta: 06/01/2016).

Essa especulação de ordem histórica ganhou uma profunda e densa confirmação com o trabalho do historiador e filósofo Amos Funkenstein. Funkenstein demonstrou que essa crença na estabilidade do mundo é o produto da secularização de certas ideias teológicas ocorrida entre os séculos XIII e XVIII. A Teologia foi uma disciplina de grande prestígio mesmo após o período medieval, sendo estudada, já nos tempos modernos, por todos aqueles que tinham maiores pretensões intelectuais, mesmo que não fossem muito religiosos.

Essas pessoas que não faziam parte do clero e nem escreviam tratados sobre temas religiosos usaram dos temas da Teologia nas suas obras sobre outras

\footnotetext{
${ }^{91}$ Idem, p. 27.
} 
disciplinas, tanto nas de Filosofia, quanto nas de Teoria Política e nas de Ciências Naturais. Pensadores como Galileu, Descartes, Leibniz, Newton e Hobbes se valeram de temas teológicos nas suas reflexões e fizeram uma espécie de Teologia voltada para as coisas do mundo, uma "teologia secular". ${ }^{22}$

Os temas da Teologia tradicional sofreram grandes mudanças nas suas versões seculares. Importante para nossa discussão é saber que a ideia de onipotência divina, passando por muitas reformulações ao longo dos séculos, acabou tornandose o que entendemos hoje por "leis da natureza". Nas palavras de Amos Funkestein:

Deus, que foi na Idade Média a fonte de toda contingência, se tornou a origem de toda racionalidade, ou dito de outra forma, a garantia metodológica da completa inteligibilidade da natureza. ${ }^{993}$

Refletindo sobre as conclusões de Funkenstein, acreditamos ser possível afirmar que, se a pesquisa científica só é possível pressupondo essa crença na estabilidade da natureza, ela também seria possível ao se basear na ideia originária da qual a crença na estabilidade nasceu, ou seja, na ideia de um Deus que garanta a "completa inteligibilidade da natureza". Historicamente, seria possível afirmar que a pesquisa medieval e moderna teria como fundamento não a versão secularizada, mas a crença original. Ou seja, direta ou indiretamente, a ciência tal qual praticada no ocidente nos últimos setecentos anos tem sua fundamentação última na crença religiosa cristã.

Como falaremos especialmente da ciência biológica, é necessário fazer mais uma consideração. Seria possível os homens prenderem, cortarem, dissecarem e testarem todo tipo de veneno e medicamento em seres considerados sagrados? Ora, algumas culturas consideraram os animais como seres especiais, seres que não deveriam ser perturbados ou que mereciam certo respeito ritual. $\mathrm{Na}$ opinião de Leszek Kolakowski o cristianismo teve o papel de retirar todos os seres naturais do campo do sagrado, abrindo caminho para sua conquista técnico-científica:

A concepção do mundo judaica e cristã, em contraste com a oriental, nunca se preocupou muito com os seres inferiores, exceto em relação com as necessidades humanas. Ao homem bíblico se deu o direito de dominar e explorar aos animais e a idéia oriental da unidade e santidade de toda vida (expressada com ênfase no jainismo, mas presente, ao que parece, em todas as ramificações do hinduísmo e do budismo) nunca foi adotada pela corrente principal do cristianismo; ao ab-rogar os tabus alimentares do Antigo Testamento, o cristianismo eliminou definitivamente as qualidades sacras vinculadas ao reino animal. São Francisco conversando com o irmão lobo e Santo Antônio de Pádua pregando aos peixes do mar em Rimini não representam em absoluto a

\footnotetext{
92 Amos FUNKENSTEIN, Théologie et Imagination Scientifique: du Moyen Age au XVIIIe siècle, Paris, Presses Universitaries de France, 1995, p.1.

${ }^{93}$ Idem, p. 229.
} 
atitude cristã típica. [...] Pode-se pensar que ao designar o homem como senhor da terra e ao subordinar a natureza às suas necessidades, a tradição judaico-cristã estimulou o grande impulso ao progresso tecnológico e científico sobre o qual iria se construir a civilização ocidental. As religiões que pregavam a unidade da vida e um respeito indiferenciado a elas não estavam adaptadas para impulsionar a conquista tecnológica da matéria. ${ }^{94}$

Evidente que esse proceso de dessacralização do mundo se deu na longa duração e, como é característico desses processos, compreendeu muitos avanços e retrocesos. Nesse sentido, é possível considerar a visão gótica da natureza como um passo importante para se estabelecer na cultura ocidental que os animais são seres totalmente naturais. Por tudo que acabamos de afirmar, acreditamos ser possível dizer que a visão religiosa expressa na arte gótica não só é compatível com o desenvolvimento das ciências naturais, como é também um fator positivo para tal processo.

\subsection{Arte gótica e a ordenação do mundo}

Como afirmamos anteriormente, estamos a buscar na arte gótica elementos relevantes para a formação de uma mentalidade científica no período medieval. Primeiramente, é necessário estabelecer algum ponto de contato entre a arte e a ciência e, depois, estudar o caso particular da arte gótica. É o que faremos agora.

A arte e a ciência, que ligações podem ter? $\mathrm{O}$ mundo das contas e das medidas não nos parece afim ao da imaginação e do sonho, o domínio da fantasia parece distar muito do da conceituação e da experimentação. Mas isso é somente parte da verdade. Observando bem, é possível notar que existem importantes relações entre a arte e a ciência. $O$ primeiro passo para compreender essas relações é entender o que é a arte. Deixemos um seu historiador nos responder:

Como principio ordenador representa um dos meios mais diretos de dominar o caos exterior e interior do homem. O desconcertante, assustador e inconcebível da vida só pode ser ordenado ao receber forma. Arte é a configuração do desordenado, que sempre significa ameaça. Desde a pré-história a atividade artística serviu à interpretação do mundo e do homem no mundo. ${ }^{95}$

A arte como ordenadora do mundo. Já nos fica patente sua relação com a ciência, pois é a essa atividade que atribuímos, no mais das vezes, a função de ordenar nossos conhecimentos sobre o mundo. E não há que se duvidar que a arte é um principio ordenador. Os diversos estilos artísticos não são, ao fim e ao cabo, diversos modos de interpretarmos, de ordenarmos, os mesmos eventos? A diferença

\footnotetext{
${ }^{94}$ Leszek KOLAKOWSKI, Si Dios no existe...: sobre Dios, el diablo, el pecado y otras preocupaciones de la llamada filosofia de la religión, Madrid, Editorial Tecnos, 1985, p.59

${ }^{95}$ Fritz BAUNGARTEN, Breve História da Arte, São Paulo, Martins Fontes, 2001, p1-2.
} 
básica entre um artista barroco e um romântico, por exemplo, não é o modo como ele percebe e ordena o seu mundo? Não é essa visão ordenadora que determina os assuntos que tratará e como os tratará? Temos, pois, uma relação estabelecida: tanto a arte quanto a ciência são formas que usamos para ordenar nosso conhecimento do mundo.

Considerando a arte dessa forma, fica claro que os diversos tipos de ordenação apresentados por ela podem abrir ao seu observador perspectivas diversas. Uma arte mais luminosa e ordenada como a gótica, que defini muito bem cada ser e seu lugar num sistema, poderia inspirar um cientista a explorar as particularidades dos seres, a dar ênfase nos eventos individuais e também na classificação. Já uma arte nebulosa como a romântica poderia levar o pesquisador a considerar o caráter orgânico da natureza, as múltiplas ligações entre os seres, as implicações das ações de uma parte da natureza em outra. Isso não é mera especulação. Pelo menos sobre o romantismo, existem estudos que apontam tais ligações.

Se a arte colabora para o melhor entendimento da ordem do mundo, é claro que uma arte que ordene melhor os elementos conhecidos ajudará aqueles que estudam a natureza a melhor compreender essa ordem. Podemos dizer que a arte gótica é um avanço frente à arte românica no tocante à ordenação, fato bem observado por Erwin Panofsky. Segundo o grande historiador, podemos ver isso em todos os campos do saber medieval por volta dos inícios do século XIII. ${ }^{96}$ Vejamos um exemplo bastante interessante do processo de ordenação ocorrido com a passagem da pintura românica para a gótica:

Na pintura, tal processo de clarificação pode ser retraçado, por assim dizer, com um experimento "in vitro". Por uma feliz coincidência, temos a possibilidade de comparar uma série de miniaturas da época de 1250 com seus modelos diretos, elaborados na segunda metade do século XI provavelmente depois de 1079 e certamente antes de 1096. As duas mais conhecidas mostram o rei Felipe na igreja de Saint-Samson, [sic] ao mosteiro de Saint-Martin-des-Champs. Enquanto o modelo do românico primitivo, um bico-de-pena sem margens, mostra uma confusão de pessoas, prédios e inscrições, a versão do apogeu gótico é uma imagem cuidadosamente ordenada. A cena é contornada por uma margem e, em função de um novo senso de realismo e de dignidade citadina, acrescentou-se uma cerimônia de sagração na margem inferior. Os diferentes elementos do quadro são aqui cuidadosamente separados, e a área compreendida entre as margens é dividida em quatro campos nitidamente delimitados, correspondendo, respectivamente, às categorias: realeza, edifício da igreja, episcopado e nobreza mundana. As duas construções, a própria igreja de Saint-Martin e a de SaintSamson, não apenas são colocadas no mesmo nível, como são também reproduzidas em vista claramente lateral, em vez de em uma projeção não-uniforme. $\mathrm{O}$ fato de que os dignatários, antes desacompanhados e

\footnotetext{
${ }^{96}$ Erwin PANOFSKY, Arquitetura gótica e escolástica: sobre a analogia entre arte, filosofia e teologia na idade média, São Paulo, Martins Fontes, 1991, p.25-26.
} 
representados em vista frontal uniforme, venham agora acompanhados de umas poucas pessoas importantes, se movam e conversem entre si, tudo isso antes realça que diminui sua importância individual. O único sacerdote que se encontra, por boas razões, entre os condes e príncipes, o arcediago Drogo, de Paris, contrasta claramente com eles por sua casula e mitra. $^{97}$

Não só na pintura, mas também na escultura e principalmente na arquitetura, vemos esse processo de ordenação sistemática de todos os elementos de uma obra. Chegamos a um ponto onde, no dizer de Georges Duby: "Coloca-se cada elemento do cosmos, cada astro, cada reino, cada ordem, cada espécie no seu lugar."”8

A história da ordenação sistemática dos variados campos da atividade humana na Idade Média foi muito bem estudada por Alfred Crosby. Segundo esse autor, podemos ver na sociedade ocidental um vasto processo de quantificação e mensuração. Esse processo seria algo único da sociedade medieval, pois mesmo na Grécia Antiga, na maioria das vezes, se valorizaria o aspecto qualitativo das coisas. Essa visão de mundo qualitativa, não-quantitativa, estaria presente na Europa da antiguidade até meados do século XIII. Os homens que vivem durante esse longo período, em muitos aspectos de suas vidas, enfatizariam o aspecto qualitativo em detrimento do quantitativo.

O tempo, por exemplo, não era dividido de uma forma igual, não havia horas iguais às outras, com a mesma duração. Aliás, as horas, quando eram contadas, eram de modo muito irregular, não havia um padrão. $\mathrm{O}$ mesmo poderíamos dizer do espaço, haviam espaços qualitativamente diferentes. A Terra era considerada qualitativamente diversa dos outros planetas, aqui é o reino da mutação, lá o da imutabilidade. Teria sido entre os séculos XIII e XIV que essa visão mudaria drasticamente:

Depois, entre 1250 e 1350, não tanto na teoria, mas na aplicação prática, houve uma mudança acentuada. Provavelmente podemos reduzir esse século a cinqüenta anos, de 1275 a 1325 . Alguém construiu o primeiro relógio e o primeiro canhão mecânicos da Europa, aparelhos esses que obrigaram os europeus a raciocinarem em termos de um tempo e um espaço quantificados. As cartas marítimas de Portolano, a pintura em perspectiva e a prática contábil das partidas duplas não podem ser datadas com exatidão, pois foram técnicas emergentes, e não invenções específicas, mas podemos afirmar que os exemplos remanescentes mais primitivos de todas três datam desse meio século, ou de um momento imediatamente posterior. Roger Bacon mediu o ângulo do arco-íris, Giotto pintou com a geometria em mente, e os músicos ocidentais, que por várias gerações tinham estado compondo um tipo pesado de

\footnotetext{
${ }^{97}$ Idem, p.29-30.

${ }^{98}$ Apud Armindo TREVISAN, O Rosto de Cristo: a formação do imaginário e da arte cristã, Porto Alegre, AGE Editora, 2002, p.149.
} 
polifonia, chamado ars antiqua, alçaram vôo com a ars nova e começaram a compor o que chamavam de "canções compassadas com precisão". Nunca tornou a haver nada que se parecesse muito com esses cinqüenta anos, até a virada do século $\mathrm{XX}$, quando o rádio, a radioatividade, Einstein, Picasso e Schönberg arrastaram a Europa para uma revolução similar. ${ }^{99}$

Esse importante movimento de ordenação se manifestou nos mais diferentes campos, como afirma a citação que sintetiza o livro. Lembremos que Dom Afonso tomou papel importante nesse processo, na quantificação do tempo ele foi um pioneiro. Em sua corte, na década de 1270, foi desenhado um "relógio movido a pesos, regulado pelo fluxo do mercúrio que ia de um compartimento de uma roda oca para o outro". 100 Nessa vasta empresa de ordenação e quantificação do mundo vemos, através dos estudos de Erwin Panofsky, que a arte gótica tem uma grande importância. Panofsky acredita que o impulso original para essa grande sistematização do mundo teria surgido na filosofia escolástica e se espalhado pelos outros campos da atuação humana por uma "difusão genérica", por ter criado um "hábito mental". 101

Já se colocou em questão essa ideia do grande historiador da arte, mas parece que a razão lhe acompanha. Dizemos isso porque, realmente, como ele já havia esboçado e como Alfred Crosby demonstrou de forma muito documentada, esse princípio de ordenação rapidamente se espalhou por todos os campos da criação intelectual medieval. Se, conforme pensa Panofsky, a filosofia foi a iniciadora desse processo de distinção e ordenação mais precisa, não podemos ignorar que a arte gótica foi um elemento de importância na divulgação dessa tendência. Em todo caso, é de se tonar que a arte gótica tem precedência de um século frente os muitos elementos que, segundo o estudo de Crosby, cooperaram para a criação de uma mentalidade que bvuscava uma ordenação mais precisa.

Os que duvidam do poder desses hábitos mentais e procuram ver na história apenas influências muito diretas de um movimento em outro repugnariam a ideia de que a melhor ordenação proporcionada pelo gótico poderia ter alguma influência na ordenação que a ciência faz da natureza. Contudo, não nos parece possível duvidar que esses "hábitos mentais", para falar com Panofsky, ou essa mentalité, conforme o dizer de Crosby, são forças verdadeiramente moventes da ação e do pensamento humano. Arthur Lovejoy demonstrou que uma ideia difusa e muitas vezes mal percebida - a de que há uma "grande cadeia do ser" que engloba todos os seres existentes - influiu nos mais diversos os campos da atividade humano por mais de

\footnotetext{
${ }^{99}$ Alfred W. CROSBY, A mensuração da realidade: a quantificação e a sociedade ocidental 1250-1600, São Paulo, UNESP, 1999, p.30-31.

${ }^{100}$ Idem, p.84.

${ }^{101}$ Erwin PANOFSKY, Arquitetura gótica e escolástica: sobre a analogia entre arte, filosofia e teologia na idade média, São Paulo, Martins Fontes, 1991, p.14.
} 
dois mil anos, como também foi importante para os pensadores mais díspares e gerou concepções até mesmo contraditórias. ${ }^{102}$

Parece-nos, portanto, correto continuar nossa investigação sobre o ordenamento do mundo através da arte gótica estudando a obra poética de Dom Afonso X. Vemos claramente que nas Cantigas de Santa Maria há uma grande organização. Tomando-a como um conjunto, veremos que para cada nove Cantigas de Milagre há sempre uma Cantiga de Louvor. Além disso, toda Cantiga terminada em cinco $(5,15,25 \ldots)$ é mais extensa, em honra do nome de Maria, que tem cinco letras. Essa ordem é observada atentamente e só encontra exceção no final do corpus com as cantigas de Festa e a Petiçon.

As iluminuras que acompanham os poemas são também muito bem organizadas. Ao contrário de boa parte das pinturas românicas, a orientação da história narrada nelas é facilmente identificável. A ação sempre começa no canto esquerdo superior e sempre termina no canto direito inferior. Os quadros são divididos com exatidão, sendo seis iluminuras para cada cantiga, salvo algumas poucas exceções. É de se notar que essa distribuição, tão vantajosa para a compreensão da narração, é "o único caso conhecido entre os códices da época". ${ }^{103}$

Para melhor inteligência do que vai desenhado, cada quadro conta com uma vinheta na sua parte superior. Nessa vinheta é dada uma narrativa muito resumida que explica o conteúdo ilustrado. Salvo raríssimas exceções, todas as cenas encontram-se bem acomodadas nos contornos dos quadros, não havendo mescla ou sobreposição de cenas. Essa ordenação, presente no conjunto, encontra-se também em cada cantiga. Sobre isso Richard Kinkade comenta o que segue:

Para alcançar seu objetivo, primeiro Afonso concebeu um sistema racional de apresentação: cada milagre seria introduzido por uma narrativa detalhando o contexto histórico geral do evento, as circunstâncias individuais da(s) pessoa(s) envolvida(s) no milagre e, finalmente, o sentido ou verdade essencial desse ato de intervenção divina sobre a dimensão humana. Em consonância com o espírito da filosofia escolástica, a narrativa foi então composta em versos cuidadosamente medidos e rimados, exaltando o princípio do paralelismus membrorum, ao mesmo tempo que aderindo com frequência à doutrina tripartida da divisão, definição e demonstração. ${ }^{104}$

Vemos que há uma preocupação de ordenar com clareza o plano da obra e cada composição. A narrativa, na maioria dos casos, pode ser compreendida com facilidade, mas as exceções não são poucas. Em alguns casos a clareza do poema é

${ }^{102}$ Arthur Oncky LOVEJOY, A Grande Cadeia do Ser: um estudo da história de uma idéia, São Paulo, Palíndromo, 2005.

${ }^{103}$ Matilde Lopéz SERRANO. Cantigas de Santa Maria de Alfonso X el Sabio, Rey de Castilla, Madrid, Editorial Patrimonio Nacional, 1987, p.39.

${ }^{104}$ Apud Bernardo Monteiro de CASTRO, As Cantigas de Santa Maria: um estilo gótico na lírica ibérica medieval, Niterói, EdUFF, 2006, p.38-39. 
prejudicada pela necessidade da rima ou por ser preciso acrescentar mais informações, quebrando a fluência do pensamento. Mas não devemos esquecer que, pelo menos algumas vezes, a menor inteligibilidade imediata de uma composição não implica em má ordenação. Pode ser o caso de se preferir um princípio ordenador ao outro. Como demonstrou a professora Ângela Vaz Leão em seu estudo sobre os deslocamentos intra e extra-sintagmáticos na Cantiga 7, Dom Afonso sacrifica a ordem direta dos elementos de uma oração para criar uma espécie de "antítese posicional" entre a Virgem e o demônio:

Santa Maria é deslocada para a posição inicial dos seis versos, e no último, o demo sen vergonha é rebaixado para o final da estrofe. [...] Com efeito, ao deslocar Santa Maria para a esquerda, o Autor lhe deu o primeiro lugar na frase, enquanto que, com o deslocamento de o demo sen vergonha para a direita, o Autor lhe deu o último lugar na frase, construindo, se assim se pode dizer, uma oposição topológica máxima, radical, entre a Virgem e o demônio. Criou-se, por esse recurso, uma espécie de significante posicional, mostrando a primazia da Virgem, que vence o demônio e o lança para o mais ínfimo dos lugares. Aliás, os três actantes presentes no "drama" da frase são hierarquizados, e essa hierarquia se traduz pela posição relativa dos três elementos: primeiro $a$ Virgem; depois nós, os humanos (representados pela desinência verbal e pelos pronomes pessoais); e finalmente, o demo. A posição de nós, humanos, entre a Virgem e o demo, é bem significativa da tensão que sofremos entre o Bem e o Mal, entre a salvação e a tentação. ${ }^{105}$

Aqui a ordem gramatical é subvertida em favor de uma ordem muito mais preciosa: a ordem teológica. Essa ordenação é cheia de significado, como deixa clara a fina análise que citamos. A consciência de ordem expressa nessa Cantiga é equivalente aos primorosos paralelismos esculpidos nos portais das igrejas góticas e às amplas e bem distribuídas narrativas presentes nos seus vitrais e em muitos outros elementos arquitetônicos.

Acreditamos que um dos papéis mais importantes da arte gótica foi o de habituar os homens a buscar uma ordenação rigorosa e inteligente dos elementos conhecidos. Esse desejo de ordem, tão bem realizado na prática artística, era um dos elementos mais valorizados pelos teóricos que se ocuparam na reflexão sobre a arte e a beleza no período medieval. O universo era visto como um todo ordenado, onde cada coisa tinha seu lugar e estava em relação com o conjunto. Sua beleza vinha da configuração harmoniosa de suas partes.

A ideia de proporção dominou completamente a reflexão estética medieval, "a estética da proportio era verdadeiramente a estética por excelência da Idade Média" ${ }^{106}$. E proporção nada mais é do que uma relação matemática, algo

${ }^{105}$ Ângela Vaz LEÃO, Cantigas de Santa Maria de Afonso X, o Sábio: aspectos culturais e literários, Belo Horizonte, Veredas e Cenários, 2007, p.164.

${ }^{106}$ Umberto ECO, Arte e Beleza na Estética Medieval, Rio de Janeiro, Globo, 1989 p.57. 
dependente de mensurações, que quantidades. Dessa forma, o mais valorizado pela teoria estética não é a expressão de sentimentos, como seria no século XIX e, talvez, atualmente. A composição formal, a ordenação dos elementos, ganha proeminência na reflexão estética do período, de forma que, "todos os tratados medievais de arte figutativa, dos bizantinos, dos monges do monte Athos ao Tratado de Cenini, revelam a ambição das artes plásticas de se colocarem no mesmo nível matemático da música." ${ }^{107}$ Essa visão medieval da proporção era tão forte que estava presente até em teorias cujo fundamento era um tanto diverso, como a estética da luz de Roberto Grosseteste. ${ }^{108}$

\subsection{Linguagem e Pensamento}

A linguagem é um fator de grande importância para as variadas atividades humanas, inclusive para a ciência. Wilhelm Humboldt, em Sobre a origem das formas gramaticais e sobre sua influência no desenvolvimento das ideias, considerava que as línguas se diferenciam em muito quanto ao seu poder de expressão e quanto à influência que exercem no seu falante. Existem línguas estimulante e depressoras da mente.

A língua apropriada para o desenvolvimento do pensamento científico deve se encontrar num estado tal que tenha riqueza vocabular e clareza nas suas articulações, mais sem exageros. Isso porque numa língua as palavras são como os objetos reais e as relações gramaticais são o nexo entre eles. ${ }^{109}$ Quando as relações gramaticais são mal desenvolvidas ou mal usadas, a articulação entre os elementos fica prejudicada e o pensamento embotado. Quando as palavras são poucas ou imprecisas, o entendimento fica prejudicado, a comunicação é falha ou, pelo menos, mais trabalhosa.

Sobre a imprecisão das palavras não há dúvida, não é sem motivo que toda ciência cria seu próprio jargão. Uma comunicação científica demanda o uso de palavras com um sentido bem fixado. É de se imaginar a dificuldade de escrever um tratado científico sempre tendo que explicar o sentido dado a cada palavra, sempre usando uma série de palavras e não expressões consagradas. Humboldt lembra que as línguas se diferem inclusive por elementos mais estruturais, como é o caso da ausência do infinitivo em algumas línguas. Evidente que tal ausência cria grandes dificuldades para a expressão mais abstrata, necessária para a ciência.

Quanto à questão da ligação dos termos numa língua Humboldt cita vários casos nos quais as palavras de ligação são ausentes ou ambíguas. A conexão entre os termos é feita pelo receptor do texto ou da fala, o que limita a precisão da comunicação e obrigaria o receptor a fazer o esforço mental de unir o que não é

\footnotetext{
${ }^{107}$ Idem, p. 58

${ }^{108}$ Ibidem, p.66-67.

109 Wilhelm von HUMBOLDT, Sobre el origen de las formas gramaticales y sobre su influencia en el desarrollo de las ideas / Carta a M. Abel Rémusat sobre la naturaleza de las formas gramaticales en general y sobre el genio de la lengua china em particular, Barcelona, Editorial Anagrama, 1972, p.14.
} 
claramente unido pela linguagem. ${ }^{110}$ Uma língua assim dificultaria o processo intelectivo. Uma língua que deixa claro as relações é simplesmente uma língua mais fácil de ser usada, uma língua mais eficaz. Não poderíamos atribuir pelo menos alguma parcela do desenvolvimento da ciência natural nos países de língua inglesa à praticidade de sua língua?

Existem aqueles que analisam a relação entre ciência e linguagem numa outra perspectiva, que é complementar a que acabamos de expor. O filosofo Eugen Rosenstock-Huessy afirma que a ciência depende da linguagem porque ela trabalha com objetos já nomeados.

Antes que qualquer coisa possa ser computada, calculada, observada ou testada, ele tem de ter sido algo nomeado, com que se falou, com que se operou, algo com que se teve alguma experiência. Com suas generalizações e numerais, a ciência priva as coisas de nomes. Mas não pode fazer isso senão com que previamente se revestiram de nomes. A ciência é uma aproximação secundária e abstrata à realidade. Devemos estar imersos e enraizados num universo nomeado, para depois dele nos podermos emancipar pela ciência. ${ }^{111}$

A mesma opinião é sustentada pelo poeta e ensaísta Michel Butor ${ }^{112}$ (1995, p.45) Outro autor, o matemático Jacob Bronowski, defenderá posição semelhante, mas mais radical. A linguagem "prefigura exactamente o modo como a ciência analisa o mundo real." ${ }^{113}$ Isso porque a ciência transformam entidades da natureza em objetos ao denomina-los e também transforma as relações entre os seres da natureza em conceitos. A linguagem transforma num objeto simplificado, mas real, vários seres diversos: aquele cachorro, o cachorro do vizinho e o passou pela rua são todos chamados de cachorro. São seres diferentes, mas a linguagem os une num só conceito, num só objeto.

Da mesma forma as relações entre os seres. Antes do cientista descrever as causas do movimento, a linguagem denomina de movimento aquelas várias alterações nos seres. A própria língua abstrai de milhares de eventos o conceito de movimento. Coçar a cabeça, correr e chutar uma bola, por exemplo, são eventos distintos que pela linguagem unificamos, chamando a cada uma dessas ações de movimento. Voltando a raciocinar com Humboldt, deveríamos dizer que quanto melhor a linguagem definir os seres e suas relações, mais ela preparará o caminho para a ciência.

Vemos então, como a ciência natural depende fortemente da capacidade expressiva de uma língua. E devemos lembrar que o desenvolvimento de uma

\footnotetext{
${ }^{110}$ Idem, p. 15

${ }^{111}$ Eugen ROSENSTOCK-HUESSY, A Origem da Linguagem, Rio de Janeiro, Record, 2000, p.218.

${ }^{112}$ Michel BUTOR, L'utilité poétique: cinq lecons de poétique rédigées pour être lues à la Villa Gillet, les 14 janvier, 18 février, 25 mars, 15 avril et 27 mai 1994, Saulxures, Circe, 1995, p.45.

${ }^{113}$ Jacob BRONOWSKI, Magia, Ciência e Civilização, Lisboa, Edições 70, 1989, p.59.
} 
língua é, por vezes, obra de artistas e filósofos que sempre procuram, ou criam, as melhores palavras para expressar seus pensamentos com mais beleza ou exatidão.

Essa influência da linguagem na ciência vai mais longe do que Humboldt tinha imaginado. Estudos recentes constataram o importante papel da metáfora na ciência. E não é um papel menor, como muitas vezes se admite, por exemplo, ao dizer que os cientistas usam de metáforas para explicar suas teorias para os leigos. O papel da metáfora na ciência, comprovadamente, vai mais longe.

Podemos ainda associar a grandes épocas uma determinada metáfora que se assumiu como representante do saber científico e que dominou não só o pensamento científico, mas também o político e o econômico e mesmo o filosófico desse período. Ao século XVII e primeira metade do século XVIII correspondeu a metáfora da máquina a que se seguiu até ao século XIX a metáfora do organismo. Newton concebeu o sistema solar como um mecanismo preciso de um relógio. Também os seres vivos passaram a ser entendidos como simples máquinas. A passagem à metáfora do organismo produziu uma inversão relativamente ao período anterior, prevalecendo a superioridade do ser natural sobre o artificial. As máquinas passaram a ser descritas como organismos e as imagens orgânicas foram substituindo as imagens mecânicas. Ao século XX especula-se se não poderá corresponder a metáfora do computador. ${ }^{114}$

Só essa citação, com a qual concordamos plenamente, já nos faz aquilatar a tremenda importância da metáfora para a ciência. Devemos considerar que realmente foi uma metáfora - tomar o mundo como se fosse um mecanismo - que regeu séculos do pensamento científico ocidental. Foi essa construção imaginária, poética, que forneceu o quadro onde Newton desenvolveria sua Física. E é a metáfora do mundo como organismo que guiará as pesquisas zoológicas de um Goethe e, mais modernamente, a Ecologia. Esses fatos são muito conhecidos, mas temos que insistir que essas idéias sob as quais se desenvolveram grandes sistemas científicos não são outra coisa que não metáforas.

Poderíamos parar por aqui, já tendo apontado o papel sem igual da metáfora nas ciências naturais. Mas sua ação não se dá somente nessa escala macroscópica: algumas teorias científicas derivam diretamente de uma metáfora. "Talvez o exemplo mais referido seja o do modelo planetário para a estrutura do átomo. $\mathrm{O}$ sistema solar forneceu o modelo e o núcleo atômico passou a ser entendido como um sol." ${ }^{.15}$ Poderíamos, seguindo a investigadora portuguesa, citar muitos outros exemplos da importância central da metáfora para o desenvolvimento da uma idéia científica. Esses exemplos iriam das idéias de Maxwell sobre o eletromagnetismo até descobertas recentes da genética e da bioquímica, passando pela teoria da evolução de Charles Darwin.

${ }^{114}$ Paula CONTENÇAS, A Eficácia da Metáfora na Produção da Ciência: o caso da genética, Lisboa, Instituto Piaget, 1999, p.69-70.

${ }^{115}$ Idem, p. 69. 
Segundo o bem documentado estudo que citamos, podemos ver que a metáfora não é, como pretendem alguns, um mero recurso para a melhor exposição de idéias científicas para leigos. Ela é usada correntemente em artigos científicos escritos por e para especialistas, se constituindo um elemento necessário para a comunicação científica. ${ }^{116} \mathrm{O}$ uso de metáforas é um procedimento constante na ciência natural, ele fornece os elementos necessários para unir seres e fenômenos diversos, para unificar os conhecimentos e transpô-los de um domínio ao outro. Sem o uso de metáforas não haveria ciência natural. Seu papel, e portanto, o papel da linguagem na ciência natural, não pode ser subestimado. Após esse estudo genérico, vejamos como é a linguagem de Dom Afonso X e de seus contemporâneos.

A ordenação do mundo promovida pela arte gótica se estende também à linguagem. Vimos que ela é um elemento importantíssimo para o desenvolvimento científico. Vimos que, segundo Humboldt, ela deve ser expressiva, rica em conotações, capaz de nomear os seres com exatidão e capaz de representar conceitos abstratos. Deve ser ainda capaz de expressar com precisão as relações entre os seres, ordenando os acontecimentos.

Se analisarmos a linguagem na Idade Média, veremos que ela teve um importante desenvolvimento. Já nos últimos anos do Império Romano, o latim estava se tornando confuso, menos elegante e preciso. Essa tendência foi agravada com a queda de Roma. Com o fim do Império e a grande invasão dos bárbaros a linguagem perdeu muito da sua capacidade expressiva. ${ }^{117}$

Num seç̧ão anterior tecemos algumas considerações sobre a linguagem medieval. Seguindo os estudos do filólogo Erich Auerbach, afirmamos que na época românica a linguagem literária era confusa, pouco expressiva e conceitualmente pobre. Quando chegamos à época do gótico assistimos a um claro aumento da capacidade expressiva da linguagem. Vemos que ela já apresenta aqueles elementos considerados importantes por Humboldt, como fica claro nas Cantigas de Santa Maria. A capacidade de representar tanto coisas quanto conceitos abstratos com exatidão pode ser observada em algumas composições, mas talvez em nenhuma como na conhecida Cantiga da Alva. Citemos apenas as duas primeiras estrofes:

Virgen Madre groriosa,

de Deus filla e esposa, santa, nobre, preciosa, quen te loar saberia ou podia?

Ca Deus que é lum' e dia, segund' a nossa natura non viramos sa figura senon por ti, que fust' alva.

\footnotetext{
${ }^{116}$ Ibidem, p. 70 .

${ }^{117}$ Erich AUERBACH, Mimesis: a representação da realidade na literatura ocidental, São Paulo, Perspectiva, 2009, 15 ed., p. 64.
} 
Virgen Madre groriosa...

Tu es alva dos alvores, que faze-los peccadores

que vejan os seus errores

e connoscan sa folia,

que desvia

d'aver om' o que devia, que perdeu por sa loucura

Eva, que tu, Virgen pura, cobraste porque es alva.

Virgen Madre groriosa... (CSM, 340 vv.2-20)

Nessas poucas linhas já vemos a palavra alva com vários sentidos. E enquanto avança, a composição continua jogando com os diversos significados da palavra. $\mathrm{O}$ poeta compõe com tal habilidade que a palavra alva é usada expressar objetos e conceitos muito diversos, muito além de seus três significados mais comuns: a veste talar, a luz que antecede o nascer do sol e a brancura física. Com a criatividade do poeta a palavra alva é usada para indicar a pureza da Virgem, sua intercessão pelos homens, o fato de ter gerado o Filho de Deus, o fato de te-1Ô precedido na vida humano, o fato de ter sido purificada por Deus desde quando foi concebida, sua vida como prenúncio da vida celeste que aguarda os que serão salvos e sua sabedoria como luz para os pecadores. A polissemia, aqui, não implica em confusão. É possível determinar qual é o significado da palavra alva em cada ocorrência. Ou seja, podemos ver que a linguagem de Dom Afonso é capaz de expor tanto objetos concretos quanto conceitos com exatidão. É uma linguagem apta ao pensamento filosófico e científico.

Essa capacidade de ir do concreto ao abstrato e do abstrato ao concreto com segurança foi muito bem explicitada por Ângela Vaz Leão no seu estudo sobre décima entre as Cantigas de Santa Maria. ${ }^{118}$ Como dissemos, é uma linguagem capaz de expressar conhecimentos de qualquer ordem, inclusive os mais elevados conceitos filosóficos e científicos.

Aliás, é um poeta como Dom Afonso que ajuda a língua alcançar esse nível de expressão. Quanto da ciência subsequente ao período medieval, ao período gótico, não se deve à linguagem desses poetas e também dos escolásticos? Poderíamos lembrar o que Alfred Crosby fala da linguagem cunhada por esses filósofos, especialmente por São Tomás de Aquino:

Nenhum escolástico trabalhou com mais habilidade ou maior economia de recursos do que Santo Tomás de Aquino. O arcabouço de sua lógica está aí para ser visto e testado, e sua prosa é um ressequido mínimo indispensável, desprovido de aliterações, figuras de linguagem ou sequer metáforas, a não ser quando a tradição o exige (Não lhe era realmente

${ }^{118}$ Ângela Vaz LEÃO, Cantigas de Santa Maria de Afonso X, o Sábio: aspectos culturais e literários, Belo Horizonte, Veredas e Cenários, 2007, p.135-143. 
possível rejeitar a poesia dos Salmos, mas ele criticou Platão pela extravagância da linguagem.) Seu raciocínio e sua linguagem são quase matemáticos: nossos tradutores às vezes usam símbolos algébricos como o melhor meio de expressar, no inglês do século XX, o que ele escreveu no latim do século XIII, embora tais símbolos não houvessem surgido nem mesmo na matemática antes da última parte do Renascimento. ${ }^{19}$

O autor não percebeu que a linguagem de Santo Tomás, além disso, tem certa cadência que facilita a memorização. Mas isso é sobressalente, basta notar que já se havia criado uma linguagem exata naqueles tempos. Tanto é assim, que o filósofo William James afirmava que quando se quer uma definição precisa, do que quer se seja, é aos escolásticos que se deve recorrer. ${ }^{120}$

As Cantigas de Santa Maria foram escritas em galego-português, mas sabemos que seu autor redigiu obras em outras línguas. Existem estudos que mostram a importância das obras de dom Afonso para o desenvolvimento do castelhano como língua de ciência. Na sua época o castelhano era uma língua popular, sem as características necessárias ao cultivo da ciência, talvez sua maior e mais influente atividade científica tenha sido dotar essa língua das qualidades apropriadas para a prática das ciências. Essa operação se deu no nível lexical, gráfico e da síntese. Quanto à síntese vejamos o que diz José Sala:

Como indica R. Lapesa, "se requería disponer de una frase más amplia y variada que la usual hasta entonces", y Alfonso X confeccionó una frase adecuada a tales necesidades, una frase extensa y compleja, pero dispuesta en una sucesión ordenada, equilibrada y razonada; una sintaxis, pues, de naturaleza lógica y, hasta cierto punto, tomista. ${ }^{121}$

Tomando os princípios de Humboldt em consideração, podemos aquilatar a importância transcendental dessa grande melhoria sintática. Quanto à escrita, o mesmo autor nos diz que Dom Afonso trabalhou pela uniformização da redação do castelhano, padronizando sua grafia e diminuindo a distância entre o som o a escrita. ${ }^{122}$ No plano lexical Dom Afonso não se deteve frente às inúmeras dificuldades. Como escrever tratados científicos numa língua falada principalmente por pessoas incultas e guerreiros muitas vezes igualmente iletrados? Dom Afonso procurou em diversas línguas o vocabulário necessário, adaptou palavras do latim, grego, árabe, ocitânico e outras línguas. Talvez tenha sido essa elevação cultural do castelhano a sua mais duradoura contribuição científica.

\footnotetext{
${ }^{119}$ Alfred W. CROSBY, A mensuração da realidade: a quantificação e a sociedade ocidental 1250-1600, São Paulo, UNESP, 1999, p.71.

${ }^{120}$ William JAMES. A Vontade de Crer, São Paulo, Loyola, 2001, p.15.

${ }^{121}$ José Luis Tornel SALA, El Tomismo y su influencia en la elaboración del castellano como lengua de cultura. EIUA, 10, 1994, p.486.

${ }^{122}$ Idem, p.487.
} 


\subsection{O realismo gótico e sua expressão da natureza}

O último elemento que consideraremos é o realismo gótico do qual já falamos anteriormente. Esse ponto é essencial, ao figurar as coisas do mundo com realismo, o artista gótico proporcionava aos que viam ou ouviam sua obra uma imagem do mundo mais exata e mais atrelada à natureza. Acreditamos que uma arte assim predispõe seu observador a uma consideração mais objetiva da natureza. Se, conforme muitos críticos, tratar a natureza de modo simbólico afastaria os pensadores do estudo dos seres físicos, tratá-la de modo natural, ajudaria a levá-los ao seu estudo.

Se antes as mentes viam na natureza símbolos, agora o que lhes é mostrado pela arte não são as coisas mesmas. A arte gótica ao representar os animais, ao contrário da românica, direciona seu espectador à natureza real e não à sua moralização. Assim vemos como a arte gótica pode ter ajudado a criar no espírito de alguns o interesse pelos animais da natureza. Essa opinião é partilhada por alguns historiadores da arte. Michael Camille, por exemplo, afirma que:

tanto os historiadores da arte quanto os da ciência pensam que a arte gótica inaugura uma mudança fundamental na atitude européia frente o entorno natural. A natureza deixou de ser uma série de símbolos e se converteu em uma série de objetos, vistos não através do espelho tipológico do infinito, mas através das lentes dos óticos aristotélicos. ${ }^{123}$

A menção de Aristóteles pode levar o leitor a pensar que a visão naturalista do gótico dependeria do pensamento do filósofo grego. Outro autor é mais claro ao colocar o desenvolvimento científico como causa do naturalismo gótico:

O espírito de curiosidade científica que estimulou por exemplo a produção de herbários manuscritos permitiu aos escultores de Paris, Bourges ou Reims, e mais tarde de Southwell, ousarem mais. Foi o caso do entalhe naturalista das formas das folhas e das cabeças de Reims, tão notáveis e tão características daquela época, a fazer caretas e rir com uma verossimilhança desconhecida no século XII, evidenciando um novo fascínio pela fisionomia e psicologia dos personagens. ${ }^{124}$

Essa dependência do gótico para com a ciência e o aristotelismo medieval nos parece questionável. Já vimos que o surgimento gótico precede as traduções de Aristóteles e que ele é também pouco anterior ao ímpeto naturalista do século XII.

É evidente que existe uma relação dialética entre esses elementos. Após a divulgação do corpus científico de Aristóteles e do desenvolvimento da ciência no

\footnotetext{
${ }^{123}$ Michael CAMILLE, Arte Gótico: Visiones gloriosas, Madrid, Ediciones Akal, 2005, p.134.

${ }^{124}$ Paul WILliamSON, Escultura Gótica 1140-1300, São Paulo, Cosac \& Naify Edições, 1998, p.2.
} 
século XIII é possível identificar uma influência desses elementos no realismo da arte gótica. Mas, se observarmos a cronologia dos acontecimentos, seremos obrigados a pontuar que a visão mais naturalista do mundo aparece no mundo medieval primeiramente na arte gótica e só depois na sua ciência. Alfred North Whitehead também é da opinião de o naturalismo medieval aparece primeiro na arte, tanto nas visuais, quanto na literária, e só depois na ciência:

\begin{abstract}
A ascensão do naturalismo na Idade Média tardia marcou a entrada no espírito europeu do ingrediente final necessário para a ascensão da ciência. Foi o surgimento do interesse tanto por objetos naturais como por acontecimentos naturais, por eles mesmos. A folhagem natural de uma região era modelada em um lugar afastado das construções posteriores, meramente como deleite expositivo daqueles objetos familiares. Toda a atmosfera da cada arte exibia uma alegria direta na apreensão das coisas que se encontravam ao redor. ${ }^{125}$
\end{abstract}

$\mathrm{Na}$ sequencia, Whitehead cita os artesãos que executavam a escultura decorativa da Idade Média tardia, Giotto e Chaucer como exemplos de artistas que apresentavam essas qualidades. Para ele, a importância do naturalismo da arte gótica para a ciência está no fato dessa arte expressar um interesse no mundo natural considerado em si mesmo.

Lynn White Jr., conhecido especialista na ciência e técnica medieval, tem uma posição semelhante. Segundo o medievalista norte-americano, a ciência moderna não é simplesmente a continuação ininterrupta do movimento científico da antiguidade; é algo novo, criado pela Idade Média, tendo interesses, pressupostos e métodos estranhos aos dos gregos. ${ }^{126}$ Esse impulso científico medieval seria mais ou menos concomitante ao nascimento da arte gótica, datando da segunda metade do século XII.

É interessante observar que o naturalismo na arte precedeu o desenvolvimento da pesquisa científica. Analisando cronologicamente as decorações com motivos de vegetais esculpidas nos capitéis vemos uma aproximação paulatina do realismo. No românico a vegetação não é identificável, são folhas genéricas. Entre 1140 e 1170 em Noyon, Laon, Provins e Paris as folhas já são vívidas, mas ainda pouco específicas. Até o 1200 há mais ênfase na vitalidade das folhas do que na imitação fidedigna da natureza. Nas três primeiras décadas do século XIII o realismo vai crescendo, de forma que as representações se tornam são exatas que é necessário concluir que o escultuor trasalho diante da planta original. Esse processo vai ganhando força de tal modo que na segunda metade do século os escultores chegam ao ponto de estudar o movimento e a ondulação das plantas. "Em 150 anos o escultor gótico exauriu as possibilidades naturalísticas de representação de seu meio material". 127

\footnotetext{
${ }^{125}$ Alfred North WHITEHEAD, Ciência e o mundo moderno. São Paulo: Paulus, 2006, p.30-31.

${ }^{126}$ Lynn WHITE JR., Natural Science and Naturalistic Art in the Middle Ages, The American Historical Review, vol. 52, n.3, 1947, p.422.

${ }^{127}$ Idem, p.427.
} 
A pesquisa botânica segue de perto a evolução da representação artística, os herbários da segunda metade do século XII deixam de ser simbólicos e místicos. Vão se tornando mais realistas de forma que o herbário de Rufinus, datado do final do século XIII, já apresenta uma "botânica descritiva no senso moderno". ${ }^{28} \mathrm{O}$ Herbário de Carrara (fig.6) retrata os vegetais com grande precisão. Na imagem abaixo é possível observar diversos elementos característicos da espécie representados fidedignamente, de forma que a tornam facilmente identificável.

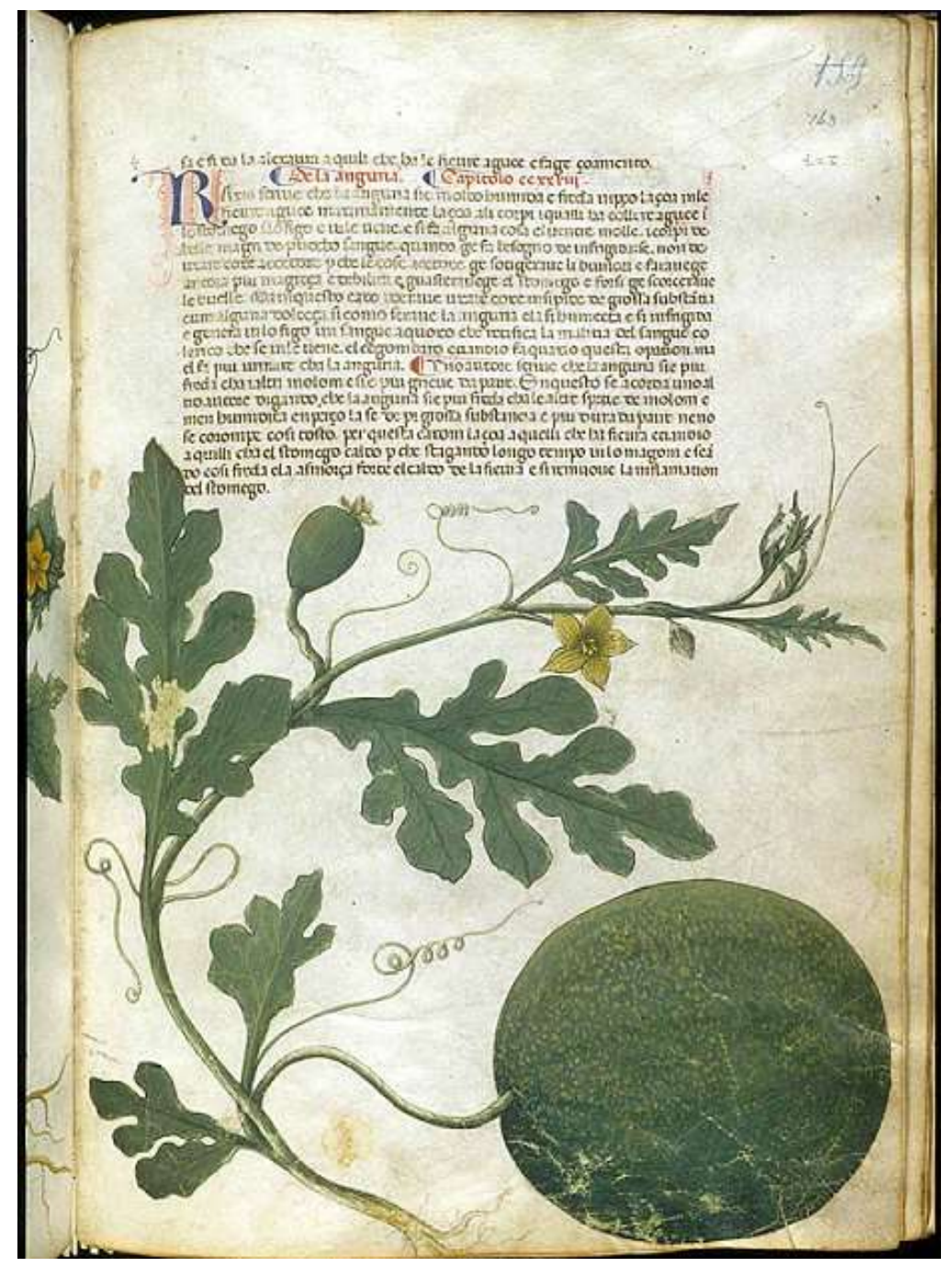

Fig.6. Melão, 1390-1404, Norte da Itália. Herbário de Carrara Ms. Egerton 2020, f.146, British Library. Imagem tomada de www.bl.uk (Última consulta: 06/01/2016).

A precedência da arte frente à ciência fica mais evidente quando se compara a representação do corpo humano. Nas obras de arte gótica do século XIII o corpo é retratado com uma verecidade muito superior a das ilustrações de textos médicos da époco e mesmo de livros desse gênero dos séculos XIV e XV. O tratamento realista do artista gótico, do escultor trabalhando em uma catedral, só será alcançado pelo ilustrador científico do Renascimento.

${ }^{128}$ Ibidem, p.427, nota 13 . 
Pedro Nava, que foi médico e escritor, afirmava que o espasmo glossofacial, antes de estudado clinicamente, foi fielmente representado numa carranca da Igreja de Notre-Dame de Dijon esculpida por volta de $1240 .{ }^{129}$ Obras como essa não poderiam oferecer aos estudiosos, medievais ou posteriores, algum insight sobre a natureza ou comportamento dos seres vivos? Poderia ser a causa de uma descoberta científica? Em todo caso, isso mostra uma atenção para com a natureza, um interesse na sua observação.

A mesma atenção que pode ser vista no famoso afresco de Giotto retratando o encontro do Menino Jesus pelos magos pintado na capela de Enrico Scrovegni, em Pádua, no ano de 1305 (Fig.7). Nessa obra a estrela de Davi ganha um forma pouco usual, mais parecida com um cometa. Seu modelo não estaria nos livros e nem em decorando catedrais, mas cruzando os céus. Seria o cometa Halley que passou pela terra em 1301. ${ }^{130}$

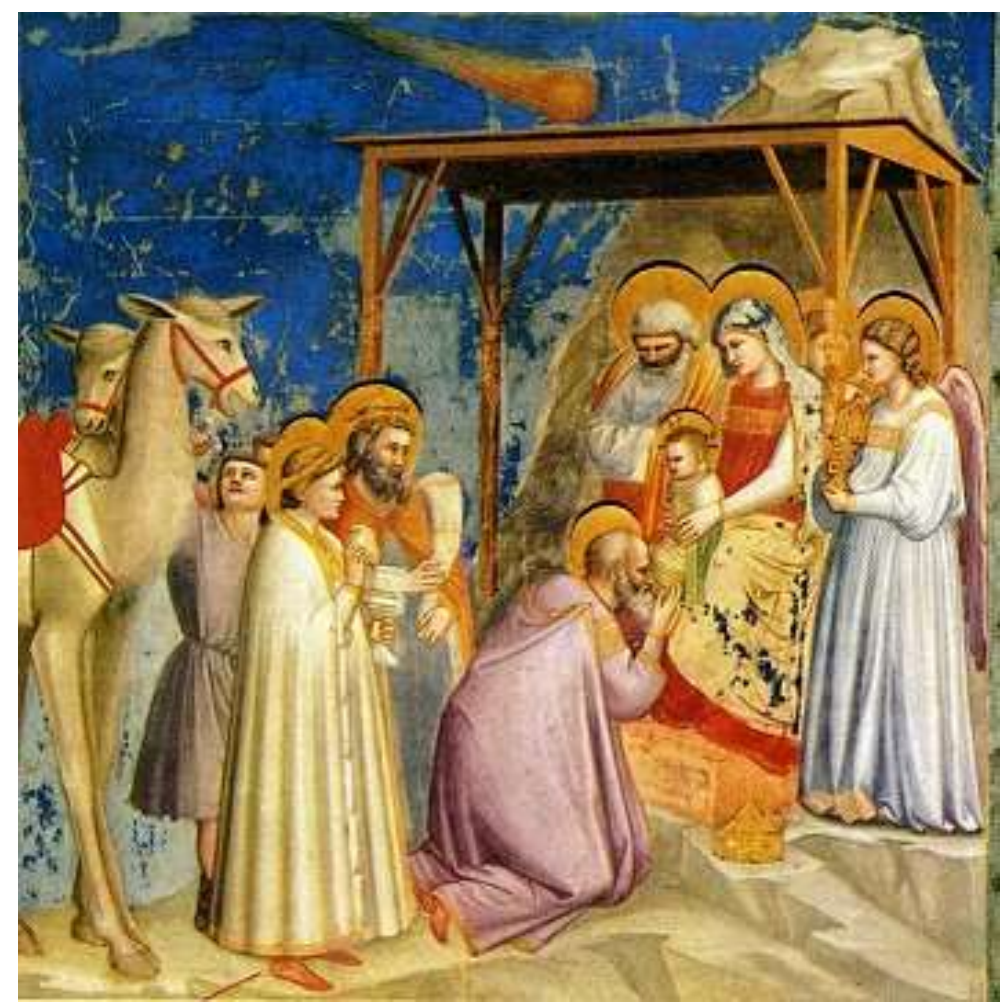

Fig.7. Giotto, Visitação dos Magos, 1303-1305. Capilla Scrovegni, Pádua. Imagem tomada de Wikimedia Commons (Última consulta: 06/01/2016).

Voltando ao tema da representação dos vegetais, podemos apontar pelo menos uma contribuição direta da arte gótica para a pesquisa sobre a natureza.

A importância do realismo da arte gótica para a ciência pode ser vista no papel dos ilustradores de herbários, livros ilustrados que descreviam as plantas e suas

\footnotetext{
${ }^{129}$ Pedro NAVA, A medicina de Os Lusíadas e outros textos, Cotia, Atelie Editorial, 2004, p.1820.

130 Ferdinando BOLOGNA, Giotto, em Georges DUBY e Michel LACLOTTE (coord.), História Artística da Europa, A Idade Média. Tomo II, Rio de Janeiro, Paz e Terra, 1998, p. 344.
} 
propriedades medicinais e eram consultados por médicos para identificar aquelas que melhor atenderiam as necessidades de seus pacientes. Podemos imaginar quão importante uma ilustração realista era para a identificação de uma planta, ainda mais numa época que a nomenclatura das plantas não era padronizada. ${ }^{131}$ Podemos apontar que a arte gótica deu uma contribuição direta à ciência, à Botânica, à Farmacologia e à Medicina, pois do século XIII em diante, seguindo os passos dos artitas góticos, mais herbários passam a ser ilustrados de forma realista, facilitando assim a identificação das plantas. A importância do desenvolvimento da arte para o da prática científica fica ainda mais clara ao pensarmos que os ilustradores de herbários do século XV aprenderam a representar realisticamente a natureza inspirados pela obra de pintores do gótico italianos como Giotto e Spinello Aretino e com os mestres do gótico flamengo. ${ }^{132}$

\section{Conclusão}

Terminado nosso estudo, retomemos o caminho. Na primeira parte estudamos brevemente a representação dos animais na literatura, concedemos particular atenção ao estudo da literatura simbólica sobre os animais. Na segunda parte fizemos um longo estudo sobre todos os animais presentes nas Cantigas de Santa Maria e pudemos notar um profundo realismo nas suas representações. Na terceira parte buscamos explicar qual era o motivo desse realismo, a hipótese de uma literatura gótica foi a resposta que procuramos apresentar. Ainda nessa parte, procuramos melhor fundamentar a idéia de uma literatura gótica, opondo-a, com mais ênfase do que já se tinha feito, a uma literatura românica.

Notamos uma mudança no modo de perceber a natureza e tentamos explorar quais poderiam ser os efeitos dessa mudança, registrada na passagem do românico ao gótico, no saber científico.

Confiamos na inteligência e erudição dos nossos eventuais leitores para corrigir os erros e imprecisões que pudemos ter comedito e, principalmente, para aprofundar as partes mais especulativas do nosso estudo. Estabelecer um paralelo rigoroso entre as obras literárias e as artes visuais do período medieval certamente levará a uma compreensão mais abrangente da mentalidade das pessoas que viveram naquela época. Estudando esses fenômenos artísticos conjuntamente, é possível que se chegue a novas compreensões, especialmente da literatura. Esperamos também que nosso estudo sobre a arte gótica e ciência medieval estimule novas pesquisas sobre esse tema tão interessante e com tantas potencialidades latentes.

Quanto ao último ponto devemos esclarecer algo. A perspectiva subjacente à secção dedicada ao desenvolvimento científico na Idade Média deve ser explicitada. Uma historiografia bastante influente afirma que a ciência é fruto da modernidade e nasce em um processo revolucionário. Subvertendo o paradigma

\footnotetext{
${ }^{131}$ Alistair Cameron CROMBIE, Historia de la Ciencia: de San Agustín a Galileo, v.1 Siglos VXIII. Madrid, Alianza Editorial, 1987, p.136.

${ }^{132}$ Idem, p. 135.
} 
medieval, os primeiros cientistas romperiam com o aristotelismo e inaugurariam um novo programa científico, com novos critérios e métodos. Nesse sentido, haveria um corte radical entre os conhecimentos tidos como científicos pelos autores medievais e a ciência de Galileu, Newton e Harvey. Iniciando-se com Francis Bacon e tendo como propagadores pensadores de todos os matizes, de Voltaire a Jacob Burkhardt, essa tese se consolidou como uma verdade histórica para uma grande parte dos historiadores e para a quase totalidade dos leigos.

Acreditamos que uma compreensão histórica mais completa e aferrada aos fatos leva a descartar essa visão. Desde Pierre Duhem, vários estudos históricos, dos quais alguns foram citados nesse artigo, vêm demonstrando que há uma continuidade, em diversos os campos do conhecimento, entre as pesquisas do século XIII e as dos séculos posteriores, inclusive no que se refere à metodologia de pesquisa científica, incluindo o uso de experimentos para confirmação de hipóteses e uma abordagem matemática aos problemas da Física. ${ }^{133}$

Os resultados dessas pesquisas históricas talvez não tenham se tornado amplamente aceitos por preconceitos e fatores teóricos. No que toca ao preconceito, devemos lembrar da permanente presença de uma lenda negra sobre o período medieval, tempo histórico considerado como de trevas para o pensamento em geral e para o científico em particular. Se essa lenda já foi desfeita pelos especialistas no período - e já o foi há décadas - sua repercussão continua em diversos meios, inclusive nos meios científicos. Apesar de uma crescente autonomia dos historiadores da ciência para com a ciência da qual pesquisam a história, não é de se descartar que os preconceitos do meio que estudam acabem os influenciando.

$\mathrm{O}$ segundo fator que nos parece levar muitos a desconsiderarem as contribuições medievais para a ciência natural é a concepção de paradigma de Thomas Kuhn. Como é sabido, Kuhn afirma que a ciência se constrói dentro de paradigmas que se sucedem historicamente e são incomensuráveis entre si. Apesar dos diversos matizes de sua obra e de correções posteriores, é possível dizer que esse é o entendimento comum de $A$ Estrutura das Revoluções Científicas. Nesse sentido, os progressos da ciência são entendidos como revoluções, cortes bruscos entre o passado e o presente. Emergindo o paradigma moderno da ciência, o que the precedeu não tem mais valor.

Essa concepção revolucionária da ciência apresenta graves problemas teóricos e, apesar de ainda encontrar adeptos, vem sendo substituída. Posturas mais flexíveis, como a de Ludwik Fleck, que não defende a existência de paradigmas incomunicáveis ${ }^{134}$, vêm ganhando espaço gradualmente. Acreditamos que essa mudança teórica poderá abrir caminho para um reconhecimento das contribuições medievais ao desenvolvimento científico.

\footnotetext{
${ }^{133}$ David C. LINDBERG, The Beginnings of Western Science: the european scientific tradition in philosophical, religious, and institutional context, prehistory to A.D. 1450, Chicago, Chicago University Press, 2007, p.357-367; Edward GRANT, Os Fundamentos da Ciência Moderna da Idade Média, Porto, Porto Editora, 2002, p.197-240

134 Ludwik FLECK, Gênese e Desenvolvimento de um fato cientifico, Belo Horizonte, Fabrefactum, 2010, p.150.
} 


\section{Fontes e Bibliografia}

\section{Fontes}

AGOSTINHO, Santo, Confissões. São Paulo, Nova Cultural, 2000.

AFONSO X, Cantigas de Santa Maria. (Edición de Walter Mettmann), Madrid, Clásicos Castalia, 1986, 3 v.

AMBRÓSIO, Santo, Exemerão. São Paulo, Paulus, 2009.

ANTÓNIO, Santo. Obras Completas. Porto, Lello \& Irmão, 1982. 2v.

ARISTÓTELES. História dos Animais. Lisboa, Imprensa Nacional-Casa da Moeda, 2006-2008. 2v.

Biblia Sagrada. (Tradução da Vulgata pelo Padre Mario Soares), São Paulo, Edições Paulinas, 1989.

CURLEY, Michael. (ed.) Physiologus: a medieval book of nature lore. Chicago: Chicago University Press, 2009.

DANTE ALIGHIERI. A Divina Comédia, (Edição Bilíngue. Tradução e notas de Italo Eugenio Mauro), São Paulo, Editora 34, 2áEd., 2010.

EDUARTE, El-Rey Dom. Livro da Ensinança de Bem Cavalgar toda Sela. (Edição. Crítica por Joseph M. Piel), Lisboa, Imprensa Nacional - Casa da Moeda, 1986.

ELIANO, Cláudio, Historia de los animales. Madrid, Ediciones Akal, 1989.

FOLIETO, Hugo de, Livro das Aves, (edição do texto latino a partir dos manuscritos portugueses, tradução do latim e introdução por Maria Isabel Rebelo Gonçalves), Lisboa, Edições Colibri, 1999.

Fuero Juzgo en latín y castellano, cotejado con los más antiguos y preciosos códices, Madrid, Ibarra Impresor de Câmara de S.M., 1815.

HONNECOURT, Villard de, O Caderno de Villard de Honnecourt, Arquiteto do século XIII. Brasilia, Editora da UnB, 1997.

PERO MENINO, Livro de Falcoaria (publicado com introdução, notas e glossário por Rodrigues Lapa), Lisboa, Centro de Estudos Filológicos, 1931, 91 p.

PERO MEOGO, As Cantigas de Pero Meogo (edição e estudo introdutório por Leodegário Amarante de Azevedo Filho), Rio de Janeiro, Editora Gernasa, 1974, $178 \mathrm{p}$.

NOLA, Roberto de, Livro do Cozinheiro. São Paulo, Instituto Brasileiro de Filosofia Raimundo Lúlio, 2010.

PIO V, São, Catecismo Romano. Anápolis, Serviço de Animação Eucarística Mariana, s.d.

RABANO MAURO, O Significado Místico dos Números. Curitiba, Editora Universitária Champagnat, 1992.

ISIDORO DE SEVILLA, SANTO, Etimologías, Edicion Bilingüe, Madrid, La Editorial Católica, Col. Biblioteca de Autores Cristianos, 2004, 1465 p.

\section{Bibliografia}

ASENSIO, Eugenio, Poetica y realidad en el cancionero peninsular de la edad media. Madrid, Gredos, 1957, 307 p. 
ASHERI, Michael, O judaísmo vivo: as tradições e as leis dos judeus praticantes. Rio de Janeiro, Imago, 1987, 368 p.

ASSUNÇÃO, Fransmarina Lourenço, Discurso masculino, milagre e simbologia nas Cantigas de Santa Maria. In: LEÃO, Ângela Vaz (org.), Novas Leituras, Novos Caminhos: Cantigas de Santa Maria de Afonso X, o Sábio. Belo Horizonte, Veredas e Cenários, 2008, p. xx-xx

AUERBACH, Erich, Figura. São Paulo, Ática, 1997, 86 p.

AUERBACH, Erich, Mimesis: a representação da realidade na literatura ocidental. São Paulo, Perspectiva, 1998, 496 p.

BARATAY, Éric, Zoologie et Église catholique dans la France du XVIIIe siècle (1670-1840): une science au service de Dieu, Revue d'Histoire des Sciences, 1995, vol. 48, n. 3, p. 241-265

BARRAL I ALTET, Xavier, O mundo românico: cidades, catedrais e mosteiros. Köln, Taschen, 1999, 237 p.

BARRETO, Marco Heleno, Imaginação Simbólica: reflexões introdutórias. São Paulo, Loyola, 2008, 103 p.

BAUNGARTEN, Fritz, Breve História da Arte. São Paulo, Martins Fontes, 2001, $376 \mathrm{p}$.

BENTON, Janetta Rebold, Bestiaire Medieval: les animaux dans l'art du Moyen Age. Paris, Editions Abbeville, 1992, 190 p.

BLUMENFELD-KOSINSKI, Renate, Not of Woman Born: Representations of Caesarean Birth in Medieval and Renaissance Culture, Ithaca, Cornell University Press, 1991, 204 p.

BOLOGNA, Ferdinando, Giotto, em Georges DUBY e Michel LACLOTTE (coord.), História Artística da Europa, A Idade Média, Tomo II, Rio de Janeiro, Paz e Terra, 1998, p. 328-357.

BONDI, Hermann, Conjetura e Mito na Física. Brasília, UnB, 1985, 53 p.

BOTNARIUC Nicolae; JAHN Ilse, "La biología en la época del Renacimiento y del capitalismo manufacturero". In JAHN, Ilse; LOTHER, Rölf; SENGLAUB, Konrad, Historia de la Biologia: teorías, métodos, instituiciones y biografias breves, Barcelona, Editorial Labor, 1990, p. 143-196.

BRONOWSKI, Jacob. Ciência e valores humanos, Belo Horizonte, Itatiaia, 1979.

BRONOWSKI, Jacob. Magia, Ciência e Civilização, Lisboa, Edições 70, 1989.

BRAGUE, Rémi, Mediante a Idade Média: filosofias medievais na cristandade, no judaísmo e no islã. São Paulo, Loyola, 2010, 328 p.

BREA LÓPEZ, Maria, DÍAZ DE BUSTAMANTE, J.M., GONZÁLEZ FERNÁNDEZ, Ignácio, Animales de referencia y animales de significación en la lírica gallego-portuguesa. Boletim de Filologia, T. XXIX, v. II. Lisboa, Centro de Linguística da Universidade de Lisboa, 1984, p. 75-100.

BURKERT, Walter, Mito e Mitologia. Lisboa, Edições 70, 1999, 81 p.

BUTOR, Michel, L'utilité poétique: cinq leçons de poétique rédigées pour être lues à la Villa Gillet, les 14 janvier, 18 février, 25 mars, 15 avril et 27 mai, 1994. Saulxures, Circe, 1995, 125 p.

CAMILLE, Michael, Arte Gótico: Visiones gloriosas. Madrid, Ediciones Akal, 2005, 192 p. 
CARPEAUX, Otto Maria, História da Literatura Ocidentel. Brasília, Edições do Senado Federal, 2008, v. 1, 542 p.

CARVALHO, Olavo de, Aristóteles em Nova Perspectiva: introdução à teoria dos quatro discursos. São Paulo, É Realizações, 2006, 172 p.

CASTRO, Bernardo Monteiro de, As Cantigas de Santa Maria: um estilo gótico na lírica ibérica medieval. Niterói, EdUFF, 2006, 236 p.

CHAMBEL, Pedro, A Simbologia dos Animais n'A Demanda do Santo Graal. Cascais, Editora Patrimonia, 2000, 155 p.

CHICO PICAZA, María Victoria, Composición, estilo y texto en la miniatura del Códice Rico de las Cantigas de Santa Maria. Alcanate, vol. V. 8, 2012-2013, p.161-189.

CHICO PICAZA, María Victoria, "Cronología de la miniatura alfonsí: estado de la cuestión", Anales de la Historia del Arte. N. ${ }^{\circ} 4$. Homenaje al Prof. Dr. D. José Maria de Azcárate. Madrid, Ediciones Complutenses, 1994, p. 569-576.

CONTENÇAS, Paula, A Eficácia da Metáfora na Produção da Ciência: o caso da genética. Lisboa, Instituto Piaget, 1999, 176 p.

COPLESTON, Frederick. Historia de la Filosofia, v.II: De San Agustin a Escoto, Barcelona, Ariel, $3^{\mathrm{a}}$ ed, 1978, 540 p.

CORTI, Francisco, "Retórica Visual en episodios biográficos reales ilustrados en las Cantigas de Santa María”, Historia, Instituciones, Documentos, n 29, 2002, p. 59-108.

CROMBIE, Alistair Cameron, Historia de la Ciencia: de San Agustín a Galileo. v. 1 Siglos V-XIII. Madrid, Alianza Editorial, 1987, 390 p.

CROSBY, Alfred W, A mensuração da realidade: a quantificação e a sociedade ocidental 1250-1600. São Paulo, UNESP, 1999, 229 p.

CURLEY, Michael. (ed.), Physiologus: a medieval book of nature lore. Chicago: Chicago University Press, 2009.

DELUMEAU, Jean, O que sobrou do Paraíso? São Paulo, Companhia das Letras, 2003, 565 p.

DOYLE, Arthur Conan, O cão dos Baskervilles. Rio de Janeiro, Agir, 2002, 152 p.

ECO, UMBERTO, Arte e beleza na estética medieval. Rio de Janeiro, Globo, 1989, $224 \mathrm{p}$.

ELLIS, Myriam, A Baleia no Brasil Colonial. São Paulo, Edusp/Melhoramentos, 1969, 235 p.

FEDELI, Orlando, Os labirintos de Eco. São Paulo, Veritas, 2007, 227 p.

FINUCANE, Ronald, The Rescue of the Innocents: endangered children in medieval miracles. New York, St. Martin's Press, 2000, 268 p.

FLECK, Ludwik, Gênese e Desenvolvimento de um fato científico, Belo Horizonte, Fabrefactum, 2010, $205 \mathrm{p}$.

FLORES, Nona, (ed.) Animals in the Middle Ages. New York \& London, Routledge, 2000, $206 \mathrm{p}$.

FONSECA, Pedro Carlos Louzada, "Animais e imaginário religioso medieval: os bestiários e a visão da natureza". In: SANTOS, Dulce O. Amarante dos, TURCHI, Maria Zaira (org.) Encruzilhadas do Imaginário: ensaios de literatura e história. Goiânia, Cânone Editorial, 2003. p. 161-178. 
FRANÇA, Susani Silveira Lemos, "Formas da verdade na poesia religiosa de Afonso X”. In: LEÃO, Ângela Vaz (org.), Novas Leituras, Novos Caminhos: Cantigas de Santa Maria de Afonso X, o Sábio. Belo Horizonte, Veredas e Cenários, 2008, p. 123-136.

FRANCO Jr., Hilário, Os três dedos de Adão: ensaios de mitologia medieval. São Paulo, Edusp, 2010, 416 p.

FUNKENSTEIN, Amos, Théologie et Imagination Scientifique: du Moyen Age au XVIIIe siècle. Paris, Presses Universitaries de France, 1995, 478 p.

GEESE, UWE, "A escultura românica". In: TOMAN, Rolf (org.), O Românico: Arquitectura, Escultura, Pintura. Madrid, Könemann Verlagsgesellschaft, 2000, p.256-323.

GEORGE, Wilma; YAPP, Brunsdon, The Naming of the Beasts: natural history in Medieval Bestiary. London, Duckworth, 1991, 231 p.

GONÇALVES, Iria, "Espaços silvestres para animais selvagens, no noroeste de Portugal, com as inquirições de 1258". In: Estudos em Homenagem ao Professor Doutor José Marques. Porto, FLUP, 2006, p. 193-219.

GOUGUENHEIM, Sylvain, Aristote au Mont Saint-Michael: les racines grecques de L'Europe chrétienne. Paris, Seuil, 2008, 277 p.

GRANT, Edward, Os fundamentos da Ciência moderna na Idade Média. Porto, Porto Editora, 2004, 277 p.

GREGORIO, Daniel, Simbolismo animal y teratología en las Cantigas de Santa Maria. Alcanete, 2006-2007, v. 5, p. 267-292.

GRIECO, Albert, "Alimentação e classes sociais no fim da Idade Média e na Renascença”. In: FLANDRIN, Jean Louis, MONTANARI, Massimo, História da alimentação. São Paulo, Estação Liberdade, 1998, p. 466-477.

GUÉRANGER, O.S.B., Dom Prosper, Missa Tridentina: explicações das orações e das cerimônias da Santa Missa. Rio de Janeiro, Editora Permanência, 2011, 156 p.

GUGLIELMI, Nilda, El Fisiólogo: bestiario medieval. Madrid, Ediciones Eneida, 2002, 184 p.

GUYÉNOT, Émile, Las Ciencias de la Vida en los siglos XVII y XVIII el Concepto de la Evolucion. México D.F., UTEHA, 1956, 395 p.

HASSIG, Debra, (ed.), The Mark of the Beast. New York \& London, Routledge, 2000, $219 \mathrm{p}$.

HAYS, H. R, Birds, Beasts and Men: a humanist history of zoology. Baltimore, Penguin Books, 1973, 383 p.

HUMBOLDT, Wilhelm von, Sobre el origen de las formas gramaticales y sobre su influencia en el desarrollo de las ideas / Carta a M. Abel Rémusat sobre la naturaleza de las formas gramaticales en general y sobre el genio de la lengua china em particular. Barcelona, Editorial Anagrama, 1972, 128 p.

KLEIN, Bruno, "A arquitectura românica em Espanha e Portugal". In: TOMAN, Rolf (org.), O Românico: Arquitectura, Escultura, Pintura. Madrid, Könemann Verlagsgesellschaft, 2000, p.178-215.

KLUCKERT, Ehrenfried, "Arquitectura da construção sacra românica". In: TOMAN, Rolf (org.), O Românico: Arquitectura, Escultura, Pintura. Madrid, Könemann Verlagsgesellschaft, 2000, p.20-31. 
KOLAKOWSKI, Leszek, Si Dios no existe...: sobre Dios, el diablo, el pecado y otras preocupaciones de la llamada filosofia de la religión. Madrid, Editorial Tecnos, 1985, $232 \mathrm{p}$.

JAHN, Ilse, LOTHER, Rölf, SENGLAUB, Konrad, Historia de la Biologia: teorías, métodos, instituiciones y biografías breves. Barcelona, Editorial Labor, $1990,780 \mathrm{p}$.

JAHN, Ilse, "El período cristiano-latino del feudalismo europeo", In: JAHN, Ilse, LOTHER, Rölf, SENGLAUB, Konrad, Historia de la Biologia: teorías, métodos, instituiciones y biografías breves, Barcelona, Editorial Labor, 1990, p. 116-139.

JEAUNEAU, Édouard, A Filosofia Medieval. Lisboa, Edições 70, 1986, 112 p.

JAMES, William. A Vontade de Crer, São Paulo, Loyola, 2001, 50 p.

LANDURIE, Emmanuel Le Roy, Montaillou, povoado occitânico 1294-1324. São Paulo, Companhia das Letras, 1997, 584 p.

LAULE, Bernhad. In: TOMAN, Rolf. (org.) O Românico: Arquitectura, Escultura, Pintura. Madrid: Könemann Verlagsgesellschaft, 2000, 479 p.

LAURIOUX, Bruno, A Idade Média à mesa. Lisboa, Europa-América, 1992, 160 p.

LEÃO, Ângela Vaz (org.), Novas Leituras, Novos Caminhos: Cantigas de Santa Maria de Afonso X, o Sábio. Belo Horizonte, Veredas e Cenários, 2008, 236 p.

LEÃO, Ângela Vaz, Cantigas de Santa Maria de Afonso X, o Sábio: aspectos culturais e literários. Belo Horizonte, Veredas e Cenários, 2007, 165 p.

LE GOFF, Jacques, A bolsa e a vida: economia e religião na Idade Média. Rio de Janeiro, Civilização Brasileira, 2007, 112 p.

LINDBERG, David C, The Beginnings of Western Science: the european scientific tradition in philosophical, religious, and institutional context, prehistory to A.D. 1450. Chicago, Chicago University Press, 2007, 480 p.

LOVEJOY, Arthur Oncky, A Grande Cadeia do Ser: um estudo da história de uma idéia. São Paulo, Palíndromo, 2005, 383 p.

MAÇÃS, Delmira, Os animais na Linguagem Portuguesa. Lisboa, Centro de Estudos Filológicos, 1951, 430 p.

MACHADO, Heloisa Guaracy, "Sobre a concepção medieval e cristã da História nas Cantigas de Santa Maria". In: LEÃO, Ângela Vaz (org.), Novas Leituras, Novos Caminhos: Cantigas de Santa Maria de Afonso X, o Sábio. Belo Horizonte, Veredas e Cenários, 2008, p. 149-166.

MAGNER, Lois N., A History of the Life Sciences. New York, Marcel Dekker, 1994, $496 \mathrm{p}$.

MAIA, Carlos Alvarez, História da Ciência, uma história de historiadores ausentes, Rio de Janeiro, EDUERJ, 2013, 306 p.

MALAXECHEVERRÍA, Ignácio, Bestiário Medieval. Madrid, Ediciones Siruela, 1993, $277 \mathrm{p}$.

MARTINS S.J., Mário, Estudos de Literatura Medieval. Braga, Livraria Cruz, $1956,536 \mathrm{p}$.

MARTINS S.J., Mário. Alegorias, símbolos e exemplos morais da Literatura Medieval Portuguesa, Lisboa, Brotéria, 1975, 316 p. 
MATTOSO, José, Fragmentos de uma Composição Medieval. Lisboa, Editorial Estampa, 1987, 307 p.

MAYR, Ernst, $O$ desenvolvimento do pensamento biológico: diversidade, evolução e herença. Brasília, Editora da Universidade de Brasília, 1998, 1107 p.

MURRAY, Peter, A Dictionary of Christian Art. Oxford, Oxford University Press, 2004, 654 p.

NAVA, Pedro. A medicina de Os Lusíadas e outros textos. Cotia, Atelie Editorial, 2004, $101 \mathrm{p}$.

NIETZSCHE, Friedrich, O livro do filósofo. Porto, Editora Rés, 1984, 132 p.

NORDENSKIÖLD, Erik, The history of Biology: a survey. New York, Tudor Publishing Company, 1936, $629 \mathrm{p}$.

O'CALLAGHAN, Joseph F., Alfonso $X$ and the Cantigas de Santa Maria: a poetic biography. Leiden, Brill, 1998, 251 p.

ORTEGA Y GASSET, José, A Desumanização da Arte. São Paulo, Editora Cortez, 1991, 93 p.

OURSEL, Raymond, Romanesque. Lausanne, Benedikt Taschen, 1967, 192 p.

PANOFSKY, Erwin, Arquitetura gótica e escolástica: sobre a analogia entre arte, filosofia e teologia na idade média. São Paulo, Martins Fontes. 1991, 133 p.

PANOFSKY, Erwin, Idéia: contribuição à história do conceito da antiga teoria da arte. São Paulo, Martins Fontes, 1994, 259 p.

PANOFSKY, Erwin, Renascimento e Renascimentos na Arte Ocidental. Lisboa, Presença, 1981, 314 p.

PANOFSKY, Erwin, Significado nas artes visuais. São Paulo, Perspectiva, 1979, $439 \mathrm{p}$.

PÉREZ ARCAS, Laureano, Elementos de zoología. Pinto, Imprenta de Gabriel Alhambra, 1863, $540 \mathrm{p}$.

PIEPER, Josef, Scholasticism: personalities and problems of medieval philosophy. New York-Toronto, McGraw-Hill Book Company, 1964, 192 p.

POOLE, Kevin R, In Search of Paradise: Time and Eternityin Alfonso X's Cantiga 103. E-Humanista: Journal of Iberian Studies, v.9, 2007, p.110-129.

ROBBINS, Mary E, "The Truculent Toad in the Middle Ages". In: FLORES, Nona C. Animals in the Middle Ages, New York \& London, Routledge, 2000, p.25-47.

RONECKER, Jean-Paul, O Simbolismo Animal: mitos, crenças, lendas, arquétipos, folclore, imaginário. São Paulo, Editora Paulus, 1997, 392 p.

ROSENSTOCK-HUESSY, Eugen, A Origem da Linguagem. Rio de Janeiro, Record, 2000, $270 \mathrm{p}$.

SALA, José Luis Tornel, El Tomismo y su influencia en la elaboración del castellano como lengua de cultura, EIUA, 10, 1994, p. 477-488.

SALISBURY, Joyce E., The Beast Within: Animals in the Middle Ages, New York, Routledge, 1994, 238 p.

SÁNCHEZ AMEIJEIRAS, Rocío, "Imaxes e Teoría da Imaxe nas Cantigas de Santa Maria". In: FIDALGO, Elvira, As Cantigas de Santa Maria. Vigo, Edicións Xerais de Galicia, 2002, p. 245-330.

SANTIAGO-OTERO, Horacio, La cultura em la Edad Media Hispana (11001470). Lisboa, Edições Colibri, 1996, 156 p. 
SARANYANA, Josep-Ignasi, A Filosofia Medieval: das origens Patrísticas à Escolástica Barroca. São Paulo, Instituto Brasileiro de Filosofia e Ciência "Raimundo Lúlio" (Ramon Llull), 2006, 597 p.

SERRANO, Matilde Lopéz, Cantigas de Santa Maria de Alfonso X el Sabio, Rey de Castilla, Madrid, Editorial Patrimonio Nacional, 1987, 74 p.

SOLALINDE, Antonio G, Antologia de Alfonso X el Sábio. Buenos Aires, EspasaCalpe Argentina, 1946, $263 \mathrm{p}$.

SOUZA, Ana Alexandra Alves de, Formas de Recepção da Psicomaquia de Prudêncio. Hvmanitas, vol.50, 1998, p. 113-125.

VAN WOENSEL, Maurice, Simbolismo Animal na Idade Média: os bestiários. João Pessoa, Editora da UFPB, 2001, xxx p.

VARANDAS, Angélica, A Cabra e o Bode nos Bestiários medievais ingleses. Brathair, v.6, n.2, 2006, p. 95-116.

VARANDAS, Angélica, A Idade Média e o Bestiário. Medievalista on line. v.2, n.2, 2006, p. 1-53.

VASCONCELOS, José Leite de, "As Maias: costumes populares portugueses". In: Opúsculos. v.5. Lisboa, Imprensa Nacional, 1938. p. 508-515.

VAZ, Henrique Cláudio de Lima, Experiência mística e filosofia na tradição ocidental. São Paulo, Loyola, 2000, 120 p.

WHITE JR, Lynn, "Natural Science and Naturalistic Art in the Middle Ages", The American Historical Review, vol. 52, n. 3, 1947, p. 421-435.

WHITEHEAD, Alfred North, Ciência e o mundo moderno. São Paulo: Paulus, 2006, p.27.

WILliAMSON, Paul, Escultura Gótica 1140-1300. São Paulo, Cosac \& Naify Edições, 1998, $301 \mathrm{p}$.

TOMAN, Rolf (org.), O Românico: Arquitectura, Escultura, Pintura. Madrid, Könemann Verlagsgesellschaft, 2000, 481 p.

TREVISAN, Armindo, $O$ Rosto de Cristo: a formação do imaginário e da arte cristã. Porto Alegre, AGE Editora, 2002, 263 p. 